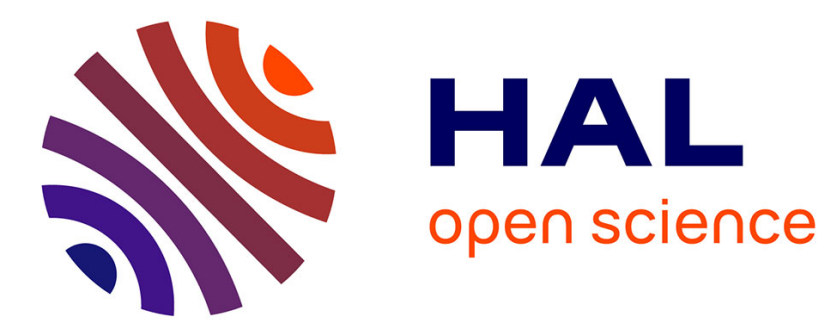

\title{
Comparative hazard analysis of processes leading to remarkable flash floods (France, 1930-1999)
}

\author{
M. Boudou, M. Lang, F. Vinet, D. Coeur
}

\section{To cite this version:}

M. Boudou, M. Lang, F. Vinet, D. Coeur. Comparative hazard analysis of processes leading to remarkable flash floods (France, 1930-1999). Journal of Hydrology, 2016, 541 (PART A), pp.533-552. 10.1016/j.jhydrol.2016.05.032 . hal-02605158

\section{HAL Id: hal-02605158 \\ https://hal.inrae.fr/hal-02605158}

Submitted on 16 May 2020

HAL is a multi-disciplinary open access archive for the deposit and dissemination of scientific research documents, whether they are published or not. The documents may come from teaching and research institutions in France or abroad, or from public or private research centers.
L'archive ouverte pluridisciplinaire HAL, est destinée au dépôt et à la diffusion de documents scientifiques de niveau recherche, publiés ou non, émanant des établissements d'enseignement et de recherche français ou étrangers, des laboratoires publics ou privés. 


\title{
Comparative hazard analysis of processes leading to remarkable flash floods (France, 1930-1999)
}

\author{
M. Boudou ${ }^{1}$, M. Lang ${ }^{2}$, F. Vinet ${ }^{3}$ and D. Cour ${ }^{4}$ \\ ${ }^{1}$ Geographer, Irstea Lyon, 5 rue de la Doua, CS 7007769626 Villeurbanne, France \\ ${ }^{2}$ Hydrologist, Irstea Lyon, 5 rue de la Doua, CS 7007769626 Villeurbanne, France \\ ${ }^{3}$ Geographer, University of Montpellier Paul-Valéry, Route de Mende, 34199 Montpellier Cedex 5, France \\ ${ }^{4}$ Historian, Acthys-Diffusion, 253 chemin de Plate-Rousset 38330 Biviers, France \\ Corresponding author: martin.boudou@gmail.com
}

\begin{abstract}
Flash flood events are responsible for large economic losses and lead to fatalities every year in France. This is especially the case in the Mediterranean and oversea territories/departments of France, characterized by extreme hydro-climatological features and with a large part of the population exposed to flood risks. The recurrence of remarkable flash flood events, associated with high hazard intensity, significant damage and socio-political consequences, therefore raises several issues for authorities and risk management policies. This study aims to improve our understanding of the hazard analysis process in the case of four remarkable flood events: March 1930, October 1940, January 1980 and November 1999. Firstly, we present the methodology used to define the remarkability score of a flood event. Then, to identify the factors leading to a remarkable flood event, we explore the main parameters of the hazard analysis process, such as the meteorological triggering conditions, the return period of the rainfall and peak discharge, as well as some additional factors (initial catchment state, flood chronology, cascade effects, etc.). The results contribute to understanding the complexity of the processes leading to flood hazard and highlight the importance for risk managers of taking additional factors into account.
\end{abstract}

\section{Keywords}

Historical hydrology - Multidisciplinary approach - Flash flood - Remarkable flood - Comparative analysis - Cascade effect

\footnotetext{
${ }^{1}$ URL: https://www.axa.fr/actualites/cout-assurances-intemperies.html

${ }^{2}$ URL:http://www.midilibre.fr/2014/12/08/intemperies-un-automne-2014-meurtrier-dans-le-sud-est-avec-17victimes, 1094596 .php\#xtor=RSS-5
} 
Author-produced version of the article published in Journal of Hydrology (2016), vol. 54, part A, pp. 533-552

The original publication is available at http://www.sciencedirect.com, doi :10.1016/j.jhydrol.2016.05.032

C. This manuscript version is made available under the CC-BY-NC-ND 4.0 license

suddenness of the hazard, such flash floods are generally associated with high fatalities compared with other kinds of floods (Jonkman, 2005; Ruin et al., 2007). This fact raises some concerns in a context of global changes associated with the constantly increasing exposure of humans and assets (SwissRe, 2015). Thus, we should bear in mind that a damaging flood event cannot be summed up as a single physical parameter, which highlights the need to carry out a multidisciplinary analysis to understand the factors involved in destructive flash flood events. As mentioned by Drobinski et al. (2014) as one of the scientific key of the HyMex project, "[...] there is a need for better understanding the social and natural dynamics of such events in order to improve the forecasting and warning capabilities of the exposed Mediterranean societies to increase their resilience to such extreme and frequent events."

Thus, a flood event is generally assessed from the viewpoint of a single discipline such as hydrology or meteorology (Borga et al., 2007; Delrieu et al., 2005), or according to a specific parameter such as risk perception (Burn, 1999) or damage/fatalities (Vinet et al., 2012). A few studies are multidisciplinary, such as the reconstruction of the 1874 Santa Tecla flash food in Catalonia by Ruiz-Bellet et al. (2015), covering history, meteorology, hydraulics and hydrology. However, a flood event is more rarely the subject of transversal studies attempting to dissect the whole flood event system by integrating both the physical and social sciences. This is especially true concerning historical events and more specifically past flash floods.

With regard to these issues, we firstly apply a multidisciplinary evaluation grid (section 2) which allows the selection of some interesting case studies. We focus here on three flash floods, occurring in March 1930, October 1940,November 1999, and one flood event resulting from a cyclonic storm in January 1980. Section 3 presents a review of the main causative factors, considering the triggering meteorological conditions, the main characteristics of the precipitation event and the peak discharge. This section concludes with an analysis of correspondence between rainfall and discharge, and focuses on additional factors explaining the hazard remarkability. In section 4, we summarize the key findings and provide recommendations on the procedure for characterizing flood events.

\section{An evaluation grid to define remarkable flood events}

\subsection{Methodology to define flood remarkability}

The EU Flood Directive especially recommends carrying out a "description of the floods which have occurred in the past and which had significant adverse impacts on human health, the environment, cultural heritage and economic activity and for which the likelihood of similar future events is still relevant...". Several issues need to be considered to meet the recommendations of the Flood Directive. How to define the "significant adverse impacts" of a past flood event? How to integrate floods from different regimes and spatio-temporal contexts into the same analysis grid? How to consider also social impacts? Scientific studies related to historical flood classification (Brazdil et al., 2006; Kundzewicz et al., 2013) or post-flood investigations of modern events (Calianno et al., 2013) are usually based on the number of fatalities and the economic damage of the flood event. The concept of flood remarkability needs to include social aspects. Some previous studies have considered both the social and hydrological components of a flood event. Creutin et al. $(2009,2013)$ took account of social aspects when assessing the lead time required for anticipation of flash floods. Ruin et al. (2014) proposed integrating a social component when conducting post-flood investigations. Llasat et al. (2009) used a press media database over the period 1982-2007 to understand the social impacts of flash floods in Catalonia.

In 2011, during the first step of the Flood Directive, which involved preparing a Preliminary Flood Risk Assessment (PFRA), the French authorities made a selection of 176 flood events from the period 1770-2010, by means of consultation with local risk managers. Several criteria were used: intense event based on flood 
Author-produced version of the article published in Journal of Hydrology (2016), vol. 54, part A, pp. 533-552

The original publication is available at http://www.sciencedirect.com, doi :10.1016/j.jhydrol.2016.05.032

C. This manuscript version is made available under the CC-BY-NC-ND 4.0 license

magnitude and/or spatial extent, diversity of flood typology, economic and social impacts, design event from flood zoning, last major event in memory, etc. The flood events considered as remarkable were then compiled into the French historical flood database (http://bdhi.fr/). Boudou et al. (2015) developed a grid with the aim of selecting the most "remarkable" amongst the 176 flood events. This grid is based on three main features: 1/ flood intensity; 2/ flood severity; 3/ spatial extent of the damages (see Fig. 1). We briefly present the three components, each being composed of a set of criteria which are themselves linked with a score (using 3 classes).

\subsubsection{The flood intensity}

The flood intensity corresponding to the hazard level of the event is composed of three criteria:

- The maximum return period of the peak discharge or the maximum return period of the rainfall episode. This indicator has the advantage that it can be used for comparing events of different nature and times of occurrence (Kundzewicz et al., 2013). The maximum score (4) linked with this criterion is based on a return period significantly longer than 100 years, in accordance with an "extreme" event of the Flood Directive.

- The maximum submersion duration recorded in the area affected by the flood event is of prime importance in the damage process according to several authors (Merz et al., 2010b; Messner and Meyer, 2006). This indicator is not especially useful for assessing the intensity of flash floods but allows integrating oceanic events associated with long flood durations into the evaluation grid. The maximum score is linked with a submersion duration exceeding 30 days, with strong impacts in terms of crisis management.

- The presence of factors aggravating the hazard level (such as dyke breaches, log jams or wave effects). These domino effects can trigger a sudden increase in flow velocity and water depth, and are often involved in the disaster process. The maximum score corresponds to aggravating factors contributing directly to an increase of the hazard level and causing the exposure of new stakeholders to the flood.

\subsubsection{The flood severity}

The flood severity is assessed by four criteria:

- The number of fatalities resulting from the flood is a key indicator frequently used to characterize the severity of a flood event (Brazdil et al., 2006). As an intangible source of damage (Parker, 2000), the number of fatalities is furthermore especially suited for retrospective analyses such as requested in the Flood Directive and, for this reason, it is used in the evaluation grid. The third class (score of 4) corresponds to an event that triggers more than 10 fatalities (minimum value also used by the CRED to integrate a natural disaster into the EM-DAT database).

- The estimation of economic damage. From 1983 onwards, we make use of the CATNAT database (www.catnat.net) which reports all damage claims supported by the current French reinsurance system for natural disasters. The third class corresponds to events with damage exceeding a value of EUR 300 billion. Before 1983, a qualitative assessment was made of the economic damage. Based on the classification drawn up by Coeur (2008), three classes are distinguished: the first class is related to sporadic submersion and the second class to sporadic destruction. The third class, corresponding to a severity score of 4 , is linked to damage or destruction of road and railway networks over a wide area and the paralysis of communication networks for more than one day.

- The social, media and political impact of a flood event. The more significant the impact of an event, the more the event can be judged as striking (and thus remarkable) for society (Merz et al., 2010a). We consider two kinds of impacts according to their time horizon: firstly the short- and medium-term impacts, referring to the crisis management and, secondly, the long-term impacts, occurring months or a few years 
after the event. The ranking of impacts into three classes is based on their spatial extent and the number of impacts. Several types of short and medium-term impacts are considered: VIP visits (President of the Republic, Prime Minister, etc.) in support of victims, national solidarity effort, extensive media coverage, rumours on the causes of flooding, unfavourable context (war, political crisis). Three main long-term impacts are also considered: establishment of a new risk management policy, judicial consequences, and event still in living memory (memorial site, films, plays, books, etc.).

7 - Aggravating factors likely to cause a significant increase in the damage level. These factors are related to two parameters. Firstly, the occurrence of failures during the warning of the exposed population and, secondly, a high incidence of solid transport or landslides during the triggering rainfall event. The score associated with this criterion is lower, and varies from 0.5 to 2 to avoid placing excessive weight on flash floods which are mainly concerned by this criterion.

\subsubsection{The spatial extent}

The spatial extent refers here to the area affected by damages and is especially important to consider for oceanic flood events which are often defined by a large impacted area. As an example, the January 1910 flood event, well known as a major flood in Paris, affected a large part of the French territory (northern and eastern regions). The spatial extent of a remarkable flood is assessed by two criteria, depending on the available information:

- The number of administrative units affected by damages. For post-1983 floods, we favour using the number of cities with natural disaster status recognized by the authorities. For floods that occurred before 1983 , the number of departments impacted is selected as an indicator of the spatial extent.

- The number of hydrographic units where a flood was selected as remarkable for the purpose of the PFRA in 2011. Such information, based on a step of subjective consultation with local risk managers, allows an estimation of the area where the event was judged as remarkable and associated with significant impacts on society (Lang et al., 2012).

\subsection{Results of application: a focus on four flood events}

The evaluation grid is applied here to a subset of 140 out of the 176 French PFRA flood events, considering those taking place after 1900, in order to obtain a homogeneous data set (available information, climatological conditions, etc.). Figure 2 shows a temporal trend, with a larger number of the selected flood events occurring during the three last decades. We should not conclude that France experienced intense flood events more often during recent decades, but rather that their impact has been enhanced by a higher exposure.

Boudou (2015) has carried out a sensitivity analysis on the weighting coefficients used for the evaluation grid. Instead of applying a geometric progression of 1-2-4 for the scores within 3 classes (Fig. 1), two alternative progressions were tested (1-3-9 and 1-1.5-3), which give greater or lesser weight to the high values. The ranking of the first 10 most remarkable events remains unchanged, as only minor changes are produced within the ranking between the $11^{\text {th }}$ and $30^{\text {th }}$ highest scores. This result gives a partial validation of the advantage of using the proposed grid.

In the present study, we focus on the $20 \%$ most remarkable floods (30 in total), associated with a score higher than 16.5. Even if floods of different typologies and spatio-temporal contexts are included in the set of events with higher remarkability scores, the results reveal that flash floods are often associated with high remarkability scores (among the 30 most remarkable events, 19 are flash floods, 10 are slow floods, and 1 is a coastal flood). This illustrates the strong potential of such events for generating flood disasters. To understand the causative factors of these remarkable flash floods, our study focuses on four events featuring 
Author-produced version of the article published in Journal of Hydrology (2016), vol. 54, part A, pp. 533-552

among the most remarkable floods: March 1930 (score: 29), October 1940 (score: 26), January 1980 (score: 21) and, finally, November 1999 (score: 29). Several reasons lead us to select these events. On the one hand, our aim is to compile a heterogeneous subset of case studies in terms of geographic area and temporal patterns. On the other hand, the subset is selected according to the specificity of each flood event. For instance, the 1930 event is associated with the second highest death toll resulting from floods during the $20^{\text {th }}$ century, thus explaining its selection as a case study. The January 1980 flood event was related to a cyclonic storm and differs from classic flash flood events occurring across the French territory. However, we assume that this episode is characterized by the same type of situation, generally resulting from a flash flood event (rapid rise in run-off on small catchments after an intense rainfall event, often causing fatalities, etc.), which is of particular importance for our study.

Based on the same multidisciplinary approach used to establish the evaluation grid, a series of monographs was produced on each aspect of these flood events, ranging from the hydrometeorological hazard features to the social and political impacts (Boudou, 2015). We then used each monograph to provide some keys to understanding the processes leading to a remarkable flood event. In this study, we focus on the factors involved in the hydrometeorological processes. A dual objective can be highlighted: firstly, to improve our understanding of the conditions of occurrence of a remarkable flood event and, secondly, assess the suitability of the indicators defining the flood intensity, which are used as input to the evaluation grid.

\subsection{Brief description of four flood events}

A short description of each flood event is presented here based on the monographs mentioned above. This description involves associating a map of the main affected rivers with the location of recorded fatalities.

\subsubsection{The March 1930 flood event}

From the $1^{\text {st }}$ to the $5^{\text {th }}$ March 1930, one of the most significant flood events of the $20^{\text {th }}$ century occurred in France. Following a heavy Mediterranean rainfall event, severe floods affected a large part of South-West France and, more specifically, the Tarn and Garonne river catchments (cf. Fig. 3a). The flood reached an exceptional magnitude, with a return period estimated at more than 200 years for the lower Tarn River according to the estimations of the flow produced by Pardé in 1930 (around $8000 \mathrm{~m}^{3} / \mathrm{s}$ for a catchment area large of $15000 \mathrm{~km}^{2}$ ). This flood led to many house collapses along the hydrographic network. Based on documentary sources, the event caused 210 to 231 fatalities, meaning that the March 1930 event was the second deadliest flood of the $20^{\text {th }}$ century (after the Malpasset dam burst in 1959, with 424 deaths). The flood event was responsible for significant economic losses estimated at around EUR 600 million. The subsequent impacts can be regarded as exceptional. For example, a day of national mourning in memory of the fatalities was instituted for the first time in France. Furthermore, a new risk policy was established, setting out a new framework for flood risk management at the national scale.

\subsubsection{The October 1940 flood event}

A major flood event affected Catalonia (i.e. the Eastern Pyrenees, both in Spain and in France) between the $16^{\text {th }}$ and $21^{\text {st }}$ October 1940. Its impacts in France were mainly concentrated along the Tech and Tet river valleys. According to the documentary sources collected, the flood event led to 57 deaths in France (Fig. 3b) and 90 in Spain (Llasat, 2004), generally resulting from house collapses (Battle and Gual, 1981). Many municipalities from the Pyrenean valleys were strongly affected, in some cases with the complete destruction of villages such as at the thermal spa of Amelie-les-Bains. Because of its occurrence during the Second World War, and in spite of huge human and economic losses, this flood event led to few consequences at the national scale. Nevertheless, the October 1940 event remains the design flood for local management policies 
as well as one of the most significant hydrometeorological events ever recorded in France since the beginning of stream-gauging measurements.

\subsubsection{The January 1980 flood event}

The January 1980 event is defined by a different typology and location compared with the other selected case studies. The flood event is linked with the occurrence of cyclone Hyacinthe that affected Réunion Island in the Southern Indian Ocean over a period of two weeks from the $15^{\text {th }}$ to the $28^{\text {th }}$ January 1980 . The exceptional precipitation triggered by the cyclone generated significant and generalized floods all over the island, leading to a great amount of damage estimated at around EUR 300 million. A total of 25 fatalities were reported (Fig. 3c), as well as extensive damage to road networks and buildings. Indeed, the January 1980 event remains a rainfall world record (Rogers et al., 2009), and spurred the creation of a new risk containment policy for the rivers of Réunion Island.

\subsubsection{The November 1999 flood event}

From the $12^{\text {th }}$ to $13^{\text {th }}$ November 1999 , a generalized flood event took place in the Languedoc region of the South of France (Fig. 3d). The Aude River and its tributaries were strongly impacted by floods, with a return period estimated at around 100 years. Due to the heavy rainfall and high flow velocities, numerous villages, roads and railways were impacted. In total, 35 fatalities were registered (Boissier, 2013), making this event the deadliest since September 1992 in France. Significant damage was recorded, with economic losses estimated at around EURO 770 million (Vinet, 2008). Owing to the reports of severe failures in the flood warning process, the November 1999 event partly contributed to the setting up of the national department of flood forecasting $\left(\mathrm{SCHAPI}^{3}\right)$ to improve the forecasting of flash floods resulting from heavy rainfall events (Chauvière et al., 2010).

\section{Characterizing the key hydro-meteorological causative factors}

\section{1. $\quad$ Methodology used for process hazard analysis of floods}

Based on the working hypothesis that the severity of a remarkable flood event depends on its level of damage and impacts, the main objective of this study is to identify the causative factors involved in defining the hazard of a remarkable flash flood event. According to de Moel et al. (2009) several parameters are commonly used to characterize a flood hazard: a/ the flood extent, which gives some indication of the flood water level ; b/ the water depth and flow velocity, also considered as involved in explaining economic losses and fatalities; $\mathrm{c} /$ the temporal flood dynamics related to propagation of the peak discharge, the flood rise rate and flood duration.

A flash flood event is commonly defined according to the spatio-temporal characteristics of the hydrometeorological event. For example, Gaume et al. (2009) regarded flash floods as events resulting from a local and heavy rainfall event (frequently exceeding $100 \mathrm{~mm}$ ), which usually affects a restricted area (less than $500 \mathrm{~km}^{2}$ ) for a short duration (generally a few hours). We also consider that a flash flood event can be defined as resulting from convective rainstorms which trigger floods with a short rise time at least in one of the catchment area affected by the precipitation event. Moreover, flash floods are characterized by specific

\footnotetext{
${ }^{3}$ SCHAPI : Service Central d'Hydrométéorologie et d'Appui à la Prévision des Inondations
} 
Author-produced version of the article published in Journal of Hydrology (2016), vol. 54, part A, pp. 533-552

The original publication is available at http://www.sciencedirect.com, doi :10.1016/j.jhydrol.2016.05.032

C. This manuscript version is made available under the CC-BY-NC-ND 4.0 license

socio-economic features such as fatalities and huge material destruction (collapse of bridges, houses, destruction of networks, etc.).

Figure 4 illustrates the systemic hazard analysis process associated with a remarkable flood event. This approach allows us to identify triggering factors related to a classic hydrometeorological event, as well as additional aggravating factors, which can then be defined as potential factors in flood hazard analysis. Each factor is linked to a series of characteristics which condition the system response.

To explore the causative factors of remarkable flood events, our methodology is supported by four main steps. Firstly, we focus on the meteorological conditions triggering the precipitation event (identified a priori as responsible for the flood event), such as the synoptic pattern or date of the meteorological event. Secondly, we consider the precipitation event itself as a triggering factor, which requires identifying parameters such as rainfall intensity to explain the contribution of precipitation to the flood process. We use the precipitation datasets provided by MétéoFrance, which are brought together within the framework of a historical database of extreme events (http://pluiesextremes.meteo.fr/). Thirdly, we characterize the hydrological response to the precipitation event by analysing original sources associated with our selected events (e.g. scientific or administrative reports produced by risk managers and/or authorities) and identifying peak discharges. Finally, we cross the indicators associated with rainfall and flood hazard, and investigate the role played by possible additional factors. This includes, for example, the initial climatological conditions of the catchment area such as the antecedent precipitation or the role of cascading effects potentially increasing the flood hazard.

\subsection{Meteorological conditions as triggering factors}

Identifying the meteorological conditions triggering a heavy rainfall event can help to define the initial causative factor responsible for the flash flood event. We focus here on the synoptic situation/pattern of these events, firstly considering flood events resulting from Mediterranean rainfall events (1930, 1940 and 1999) and then the case of the January 1980 flood event, which resulted from a tropical cyclone on Réunion Island.

\subsubsection{Meteorological context of Mediterranean rainfall events}

Flash floods in southern France are commonly triggered by the occurrence of heavy rainstorms associated with a Mediterranean depression. As the three selected Mediterranean events show quite similar synoptic situations, we deal primarily here with the October 1940 flood. Based on the NOAA $20^{\text {th }}$ century reanalysis (20CR), covering available data since 1871 (Compo et al., 2011), Figure 5 presents the atmospheric conditions on the first day of the triggering rainfall event $\left(16^{\text {th }}\right.$ October 1940).

A low-pressure system extended from Great Britain to North Africa, with its centre located to the south of the Iberian Peninsula. At the same time, a high-pressure system located in Russia created a situation of atmospheric blocking. Forced by the atmospheric circulation pattern, south-south easterly winds were fed by warm and humid air masses over the Mediterranean Sea. This flow direction generated a succession of rainy fronts. Accentuated by the orographic effect produced by the Pyrenean Mountains, this situation triggered an extreme rainfall event from the $16^{\text {th }}$ to the $21^{\text {st }}$ October 1940 in the French and Spanish Catalonia, with a maximum precipitation of $1000 \mathrm{~mm}$ in one day.

However, the type of atmospheric pattern responsible for triggering the precipitation event of October 1940 is relatively common for Mediterranean heavy rainfall events (similar pattern for the flood events in March 1930 and November 1999) and cannot entirely explain the exceptional nature of the disaster. For instance, Llasat et al. (2005) showed that such atmospheric conditions were especially responsible for most of the Mediterranean flood events occurring in Spanish Catalonia from 1840 to 1870 . Additional investigations are 
Author-produced version of the article published in Journal of Hydrology (2016), vol. 54, part A, pp. 533-552

The original publication is available at http://www.sciencedirect.com, doi :10.1016/j.jhydrol.2016.05.032

C. This manuscript version is made available under the CC-BY-NC-ND 4.0 license

required to distinguish between convective and/or non-convective cells. For example, Delrieu et al. (2005) has provided a more detailed analysis of the September 2002 flood event in the department of Gard in France, based on atmospheric data (at the surface, at $500 \mathrm{hPa}$ and $1.5 \mathrm{PVU}$ heights, equivalent potential temperature, radio soundings, etc.) as well as radar and rain-gauge datasets.

\subsubsection{The extra-seasonality of the March 1930 precipitation event}

The occurrence date of the rainfall event helps to characterize the hydrometeorological hazard. Extreme Mediterranean rainfall events usually occur during the autumn, as in the case of the October 1940 and November 1999 events. On the contrary, the 1930 flood event resulted from a precipitation event at the end of the winter. After antecedent precipitation from $25^{\text {th }}$ to $28^{\text {th }}$ February, heavy rainfall affected the Tarn river catchment area from the $1^{\text {st }}$ to the $3^{\text {rd }}$ March. The unusually late date for a Mediterranean rainfall event, with a large spatial extent and intensity (Antoine et al., 2001), should be considered as one of the striking features of this remarkable flash flood, associated with specific initial climatological conditions over the catchment, such as the soil moisture state or the presence of snow cover.

\subsubsection{January 1980 and the erratic path of the Hyacinthe cyclone}

Similarly, the synoptic situation of the January 1980 event highlights the specific nature of the meteorological conditions that triggered the event. The storm trajectory can be judged as highly anomalous compared with classical tropical cyclones, which generally come from the northern sector (56\% North-East, $38 \%$ North-West) (Mayoka, 1998). Due to its erratic path (Fig. 6), Hyacinthe crossed the coasts of Réunion Island three times, triggering an exceptional rainfall event in terms of duration and intensity. In fact, precipitation never ceased from $15^{\text {th }}$ to $28^{\text {th }}$ January, with variable intensity depending on the distance of the storm from Réunion Island (Direction de la Météorologie, 1980).

\section{3. $\quad$ Characterization of the precipitation event}

Table 1 reports the amount of precipitation during four remarkable flood events.

Some maximum values are especially noteworthy, such as the amounts of precipitation for the October 1940 or January 1980 events, which figure among rainfall records. The daily precipitation of $1000 \mathrm{~mm}$ measured at Saint-Laurent-de-Cerdans on $17^{\text {th }}$ October 1940 is considered as the European rainfall record for this duration. This value is issued from the observations of a teacher at the time of the disaster by measuring the rainfall quantity in a bucket. According to Gaume et al. (2015), the volume of the bucket may have been over-estimated so the final validation of this record remains under discussions. However, the comparison with other local rainfall data at official rain gauge stations ( $840 \mathrm{~mm}$ in La Llau for the same day), and the numerous details provided by the teacher to the authorities allows validating the magnitude of this record.The value of $6051 \mathrm{~mm}$ recorded over 12 days in the Commerson crater during the cyclone Hyacinthe in January 1980 remains a world record. At a first order of approximation, the March 1930 and November 1999 rainfall values would appear less exceptional. Nevertheless, as illustrated further below, additional features should be considered, such as the spatial extent of the $300 \mathrm{~mm}$ isohyet in November 1999 (section 3.3.1.) or the initial conditions of the catchments in March 1930 (section 3.6.1.).

\subsubsection{Spatial distribution of precipitation during a flash flood event}

Figure 7 illustrates the precipitation fields recorded during the Mediterranean events (1930, 1940 and 1999) based on a simple kriging of the rain-gauge data.

Different patterns of rainfall episodes can be observed leading to remarkable flash flood events. According to the documentary sources and the rainfall map, the precipitation that occurred during the 1930 event was not 
only unusual for its late occurrence but also for its large spatial extent from SE to NW. The high rainfall intensity (estimated at around 400 to $700 \mathrm{~mm}$ ) covered a large part of the Tarn catchment area, rarely exposed to such extreme conditions. In the same way, the November 1999 rainfall event, although defined by a shorter duration, can be considered as an extensive Mediterranean event. The area affected by more than $300 \mathrm{~mm}$ of precipitation extended northward from the Pyrenees to the Cevennes Mountains, with a strong rainfall gradient from east to west. For the October 1940 event, rainfall mapping yields a rather different spatial pattern of rainfall. The spatial extent appears more limited compared with the two other examples, but the event is characterized by stronger rainfall intensities. The highest amounts of precipitation (locally reaching a maximum of $1930 \mathrm{~mm}$ ) are clearly concentrated on the Têt and Tech catchments, close to the Spanish border. A second high intensity core (around $300 \mathrm{~mm}$ over the Montagne Noire massif) is also identified, which could account for the damage recorded in the Aude catchment area. Mapping the spatial precipitation field provides useful information for locating areas exposed to flood risk, but it does not give a clear picture of those areas exposed to the most remarkable floods. In the following, we investigate the effect of rain-gauge density and the impact of climatological features on cumulated rainfall.

\subsubsection{Limitations of spatial information}

The quality of spatial interpolation is directly linked to the density of the rain-gauge network. As the number of rain gauges was lower in the past, the uncertainties associated with spatial fields will be larger when dealing with the events in 1930 and 1940 compared with those in 1980 and 1999. Figure 8 presents two rainfall maps illustrating the January 1980 precipitation event: (a) by including all the 136 rain gauges available for this event, (b) by including only 57 rain gauges, which correspond to the stations used by MétéoFrance for climatological studies on a monthly scale. The significant differences in precipitation shown on map (c) are obtained by subtracting the values of map (a) from map (b). The rainfall field is clearly smoothed by using a less dense rain-gauge network. Some areas show a large overestimation (between 1500 and $3000 \mathrm{~mm}$ ), while other areas, such as the centre of the north of Réunion Island, are underestimated. The density of the gauging network has then to be considered carefully by the cartographer, especially when the past rain gauge density network was clearly not adapted to the spatial extent of an extreme event. This is the case for the October 1940 precipitation event (see Fig. 7b). The spatial interpolation for this event is obviously constrained by the maximum value of Saint-Laurent-de-Cerdans (1 $930 \mathrm{~mm}$ in 4 days) and reflects the oversimplified representation of the rainfall event.

Although we focus here on the significance of the gauging network density, we also need to consider some other limitations of rainfall mapping (such as the data uncertainties and availability, or the kriging method used for interpolation).

\subsubsection{Climatological features of the affected area}

Rainfall mapping of the January 1980 event shows a concentration of high precipitation values (more than 1 $500 \mathrm{~mm}$ ) along the relief as well as in the southern and eastern parts of the island (Fig. 8a). Additional information is provided by Fig. 9, based on the ratio of precipitation during the 1980 event to the January interannual mean precipitation. The mapping is supported by a geographic division of Réunion Island into five zones, considered as experiencing homogenous climatological conditions according to MétéoFrance.

The ratios reported above confirm the strong intensities attained by precipitation during the flood event. The cumulated rainfall during the event ( 13 days) is $500 \%$ more than for a normal month of January over the entire island. Some local observations even exceed the annual mean rainfall (Humbert and Bargeas, 1986). Furthermore, unlike the previous rainfall mapping, the highest ratios with respect to the mean are observed on the west coast. Usually, the east coast (also called "windward coast") is more frequently affected by cyclonic episodes. On the contrary, the West Coast (also called "leeward coast") is protected by an 
orographic barrier due to the high elevation of the volcanic relief (culminating at $3071 \mathrm{~m}$ ) and is thus generally preserved from heavy rainfall events. The information provided by the average precipitation ratios allows us to refine the characterization of precipitation during the flood by highlighting the influence of orographic conditions. However, this indicator is of limited use for correctly assessing the area of rainfall (see section 3.3.2). This sheds light on the specific pattern of the January 1980 cyclone. The erratic track of the Hyacinthe cyclone (Fig. 6), associated with classic easterly winds during the first few days (17-18 January), was followed by several changes of direction. This explains why the west coast was more affected than usual. Figure 9 provides some supplementary information compared to the raw data (Fig. 8a), since the latter are influenced by orography and do not reflect the specific nature of the event.

\subsubsection{Return periods for extreme rainfall events}

Concerning the example of the rainfall triggered by the Hyacinthe cyclone, the observed precipitation needs to be linked to the local climatology of the affected area. The return period is generally used to overcome these limitations by ranking raw data within the whole data series, which allows us to define the local exceptional nature of the rainfall. Figure 10 gives the local return period at each rain gauge for the three Mediterranean flash floods using the following durations: 5, 4 and 2 days (respectively on March 1930, October 1940 and November 1999). We use a database of rainfall quantiles produced by MétéoFrance (1999) for cumulated durations ranging from 1 to 10 days for 3000 rain gauges and estimated from the observations during the period 1961-1998

The return periods on Figure 10 indicate a different pattern compared with the raw data mapping derived from Figure 7. Even though each event comprises at least one rain-gauge value exceeding the 100 year return period, some areas are especially well pointed out by the mapping. Such is the case, for example, in the southern part of the Tarn catchment area for the March 1930 event (a), or the Aude catchment area for the November 1999 event (c). The difficulty of dealing with sparse historical data emerges when mapping the 1940 October event (b). Due to the restricted area affected by high rainfall intensity and the low density of the rain-gauge network in this same area, the interpretation is biased: just one station exceeds a 100 year return period. A similar situation would appear to apply for the November 1999 event, using the same gauge network density. A more advanced way to assess the return period of extreme precipitation is to consider areal precipitation rather than just local precipitation. Instead of Intensity-Duration-Frequency curves, Neppel et al. (2001) produced distributions of areal rainfall. These authors concluded that the November 1999 event is remarkable considering the spatial extent of the 300-mm isohyet with a return period of about 1000 years.

\subsection{Characterization of the hydrological response: peak discharge}

The output of a catchment in response to a rainfall signal can be characterized by its peak discharge. As shown on Figure 11a in relation to the November 1999 event, an aggregative effect linked to the size of the catchment area generally induces an increase of peak discharge from upstream to downstream (Marchi et al., 2010). This does not indicate any correspondence between the rainfall and the discharge mapping. By using the specific peak discharge, we can overcome this scale effect and locate the main catchment area affected by the rainfall event. The November 1999 map (Fig. 11b) shows that the most significant specific discharge values (higher than $4 \mathrm{~m}^{3} \mathrm{~s}^{-1} \mathrm{~km}^{-2}$ ) were recorded in the Aude sub-catchments (such as Orbieu), or in the Berre and the Agly catchments. Gaume et al. (2004) reported that some areas were even affected by a specific discharge exceeding $10 \mathrm{~m}^{3} \mathrm{~s}^{-1} \mathrm{~km}^{-2}$ during the event, in close relation with the 400-mm isohyet. With regard to the November 1999 example, the specific peak discharge allows us to point out the rainfall event intensity and locate the most impacted rivers. However, this parameter remains strongly correlated with the size and 
Author-produced version of the article published in Journal of Hydrology (2016), vol. 54, part A, pp. 533-552

The original publication is available at http://www.sciencedirect.com, doi :10.1016/j.jhydrol.2016.05.032

C. This manuscript version is made available under the CC-BY-NC-ND 4.0 license

hydrometeorological features of the catchment area and does not provide a fuller knowledge of the processes leading to a remarkable flood event.

To characterize the hydrological response to flash-flood precipitation, the next step consists of mapping the return period of the peak discharge along the river network. The flood intensity is estimated at each gauging station, and a wire frame is used to consider homogenous values along longitudinal sections. As discharge estimations and their corresponding return periods are affected by uncertainties (measurement, rating curve and distribution errors), the results are presented in four classes of return period (1-10, 10-50, 50-100 and > 100 years). Figure 12 shows various spatial patterns obtained during the three selected Mediterranean flood events, in 1930, 1940 and 1999. As some heterogeneities may not be detected, some parts of the river network nevertheless need to be carefully considered, such as upstream rivers or stretches impaired by the presence of hydraulic structures.

All three events were associated with extreme floods with a return period of more than 100 years. This aspect can be partly explained by the choice of the return period as a remarkability indicator during the hazard evaluation process, and also highlights the exceptional nature of the hydrological hazard. This strong intensity of the event can be concentrated in a single catchment area, such as in the lower reaches of the Tarn during the March 1930 flood or in the Orbieu (tributary of the Aude River) during the November 1999 flood. On the contrary, exceptional return periods can be spread over several catchment areas, as during the October 1940 flood event (Agly, Têt and Tech Rivers). The March 1930 and November 1999 flood events are however defined by a larger spatial expansion, with flood return periods generally estimated at around 50 to 100 years.

\section{5. $\quad$ Crossing rainfall intensity and return period of peak discharge}

Crossing the precipitation data with the peak discharge return period provides some indication for assessing the impact of the rainfall event in terms of hydrological hazard during a remarkable flood event. Based on the subset of the four case studies, two situations are presented here.

\subsubsection{Influence of precipitation event intensity on peak discharge}

Several remarkable flash flood events show a good correspondence between rainfall and flood intensities. This is the case of the flash flood event of October 1940 in the East Pyrenees. According to Figure 13, rivers affected by floods with a return period of more than 100 years are mainly concentrated within the $800 \mathrm{~mm}$ isohyet. This emphasizes the influence of the epicentre of the precipitation on hydrological hazard. We can observe that the return period remains extreme over the whole of the Têt catchment area while it decreases on the Tech River. This shorter return period on the downstream part of the catchment area can be explained by flood plain enlargement in this section, which was also less impacted by the rainfall event. At a global scale, however, the exceptional rainfall event can be considered as the main causative factor leading to the remarkable flash flood event of October 1940.

As the amount of precipitation is partly correlated with the altitude, due to orographic influence, it is better to compare the return period of both rainfall and peak discharge. Figure 14 shows a strong correlation between precipitation and peak discharge on the November 1999 flood event. This is especially true for the area from the Agly River in South to the Agout River in the North, where is located the epicentre of the rainfall intensity of the episode.

\subsubsection{Contribution of structural factors to flood return period}


The third case study, related to the cyclone Hyacinthe in January 1980, highlights an apparent lack of correlation between rainfall values and hydrological return periods (Fig. 15). As a world record, the rainfall event on Réunion Island is undoubtedly exceptional, but it did not trigger a flood with a long return period of peak discharge. Despite a large area being affected by precipitation higher than $3000 \mathrm{~mm}$ in 15 days, only one single river of the island recorded a peak flow with a return period in excess of 50 years (the Ravine du Chaudron). In the same way, while the ratio of cumulated rainfall reveals a higher rainfall intensity on the West coast (Fig. 9), the main hydrological impacts seem, on the contrary, to be concentrated on the eastern part of the island.

The non-extreme return periods connected with the peak flows during the January 1980 flood event can be explained by the morphology of the catchment area. Due to the high elevation of the island, mainly due to the activity of two volcanos (Piton des Neiges, $3071 \mathrm{~m}$; Piton de la Fournaise, $2632 \mathrm{~m}$ ) and its small size $\left(2512 \mathrm{~km}^{2}\right)$, the hydrographic network of Réunion Island is composed of a large number of small catchments (a few dozens of $\mathrm{km}^{2}$ ), that connect with the sea through deep gorges locally named ravines. The response time of these ravines is only a few hours. In comparison with other cyclone episodes (such as the cyclone Gamede in 2007), the rainfall intensity triggered by Hyacinthe, even though exceptional over periods from 1 to 15 days, was not exceptional for short durations (a few hours). The geographic configuration of Réunion Island thus explains the short return periods attained by the floods.

However, as mentioned above, peak flow is only one of the characteristics of flood hazard. Considering the duration of exceedance of the discharge threshold, Hyacinthe would remain one of the most extreme flood events that has occurred on Réunion Island from the beginning of gauging records. This long duration contributed directly to the flood event remarkability. For instance, a large proportion of the 26 fatalities resulted from dangerous and individual behaviours (such as pedestrians crossing rivers in flood). This kind of individual risk taking is partly related to a difficult crisis management, which was inappropriate for an unusually long flood event such as Hyacinthe cyclone.

The example of the January-1980 event points out the role of the physical setting of the catchment area in controlling the processes leading to a remarkable flood. It is therefore necessary to choose appropriate characteristic durations of rainfall and discharge when characterizing the rainfall and flood hazards.

\section{6. $\quad$ Additional factors explaining hazard remarkability}

\subsubsection{Initial catchment state: antecedent precipitation and snow cover}

Since the response of the drainage basin is dependent on the initial state of the soils and its interception capability, we address here the role of antecedent precipitation and then the influence of snow melting.

The contribution of previous precipitation events is usually judged as one of the classical triggering factors of generalized oceanic flood events. In the case of flash floods, usually resulting from a single and heavy rainfall event, this parameter is less significant and often neglected. According to both documentary sources and instrumental data, the contribution of antecedent precipitation is not mentioned for most of the events in our subset. For example, the October 1940 rainfall event occurred after a relatively dry summer with precipitation less than the interannual mean. A recovery of rainfall activity is recorded during the month of September 1940, with precipitation values nevertheless remaining close to the average mean values. According to the post-event feedback and the precipitation intensity of this event, the contribution of antecedent precipitation cannot be invoked as a causative factor. A similar assessment can be made for the January 1980 and November 1999 flood events. 
Unlike the three examples given above, the remarkability of the March 1930 event is closely related to the initial state of the catchment and the antecedent precipitation. The precipitation related to this event occurred very late in the season, after a series of Mediterranean rainfall events inducing especially wet winter conditions in the South West of France and a high soil moisture in the catchment area affected by the flashflood precipitation (Dougados and Gaussen, 1930; Pardé, 1930). The significance of this antecedent precipitation (Fig. 16a), generally greater than $500 \mathrm{~mm}$ for the main catchments impacted, directly contributed to increasing the flow coefficient and, as a consequent, the level of the hydrological hazard.

In the same way as antecedent precipitation, snow melting can be considered as an additional factor leading to remarkable flash flood events. This factor is regularly mentioned by the media and local population as one of the key issues of the disaster for past flood events (before the 1950s), and has often aroused debate between risk managers, as was the case after the October 1940 event. At present, it seems that this factor played a negligible role for this event in comparison to the exceptional precipitation observed (1000 $\mathrm{mm}$ in one day; $1930 \mathrm{~mm}$ in five days). Indeed, considering that the event occurred in October, only a small part of the catchment area would have been covered by snow. On the contrary, because of the occurrence of the February-March 1930 rainfall event in the late winter, the contribution of snow melting has to be considered as a causative factor of the flash flood. In fact, textual sources mention an extensive snow cover around $25^{\text {th }}$ February 1930 (with a snow cover limit estimated at $500 \mathrm{~m}$ elevation). For instance, about $20 \mathrm{~cm}$ to $1 \mathrm{~m}$ snow depth is recorded close to the sources of the Tarn River in the north-eastern part of the catchment area (Fig. 16b). The mild spell brought by the depression triggered a significant melting of the accumulated snow leading to two main consequences (Lambert, 1991);

- a supply of around one quarter of the total volume of the mountain river floods such as in the Thore and the Agout rivers

- an increase of the runoff coefficient (also issued from the high saturation state of the catchments affected), passing from $30 \%$ during a classical flood event to $90 \%$.

The example of March 1930 flood event shows that the initial catchment state has to be carefully assessed by public authorities in order to forecast flash floods. While the rainfall-event intensity remains the main triggering factor, antecedent precipitation and snow melting can nonetheless play a significant role in generating the hazard associated with a remarkable flood event. The remarkability of the March 1930 event must be directly linked to the combination of conditions favourable for the triggering of an extreme event as mentioned by Pardé (1930). More recently, the catastrophic floods of June 2013 in the French Pyrenees were also strictly linked to the input from snow melting, which raised some concerns since the damage recognition carried out by French authorities is normally based on the rainfall return period.

\subsubsection{The flood chronology}

Understanding the flow dynamics contributes to highlighting additional factors leading to the remarkability of a flash flood event.

\section{- Coincidence effects}

By analysing the flood chronology, we are able to point out the role played by coincidence effects during the process generating the flood hazard. For instance, during the November 1999 flood event, a strong swell slowed down the evacuation of flood waters at the catchment outlet. In a similar way, during the March 1930 flood event, an unfavourable timing of peak discharge produced a coincidence effect in the Tarn catchment area between the main stream and its tributaries (Pardé, 1930). This coincidence effect resulted from the specific features associated with the hydrometeorological hazard.

From 8:00 on $1^{\text {st }}$ March to 8:00 on $2^{\text {nd }}$ March 1930 (Fig.17a), precipitation was mainly located on the eastern part of the upstream Dadou, Agout and Thore catchments as well as in the middle reaches of the Tarn River 
and the upper part of the Aveyron catchment. An initial rise in water level (Fig. 18) is recorded during the night from $2^{\text {nd }}$ to $3^{\text {rd }}$ March 1930, both at Albi (Tarn River) and Castres (Agout River). The following day, the rainfall-core remained in the Agout catchment and in the middle part of the Tarn catchment (Fig. 17b), leading to two main consequences. Firstly, the precipitation contributed to a rise in water level, especially for the torrential streams located in the south of the Tarn catchment area, such as the Agout and the Thore Rivers, yielding exceptional return periods. Secondly, the persistence of heavy precipitation on both the Tarn and Agout catchments, as well as the high runoff-coefficients induced by the antecedent precipitation and snow melting, contributed to unusual flood coincidence between the Tarn River and its tributaries (Fig. 17c). To discuss this aspect, we can focus on the flow propagation. According to Figure 18, the peak flow of the Agout River in the town of Castres occurred in the early hours of $3^{\text {rd }}$ March. A short while later on the same day, the flood joined the Tarn River, whose level was already close to its maximum according to the Albi gauging station. The coincidence between the two flows produced a first-ever flood downstream from the confluence, which partly explains the long return period of the peak discharge and, as a result, the concentration of damage and fatalities along the lower part of the Tarn River (Fig. 3a).

An analysis of flow coincidence effects during the March 1930 flood event shows the influence of the spatiotemporal parameters of the precipitation during the process leading to a major flood event. A similar assessment was carried out by Schröter et al. (2015) concerning the June 2013 flood event in Germany. In fact, the exceptional nature of the flood event partly resulted from the unusual simultaneity of flood peaks, especially on the Elbe catchment area. Along the same lines, Creutin et al. (2013) showed that the temporal pattern of the hazard directly influences the social and individual response during a flood event. A PhD thesis on remarkable floods (Boudou, 2015) has pointed out that this aspect plays a role on the short term (during the crisis period) and can be involved, for example, in explaining flood fatalities. The cited study also pointed out that the spatio-temporal features of a flood hazard can influence flood remarkability on the long term by generating a favourable or unfavourable setting for social consequences.

\section{- Contribution of karst terrains}

As well as unfavourable coincidence effects, the analysis of flood propagation during remarkable flash flood events reveals that geological factors have an impact in determining the process leading to the hazard. This is especially the case in catchment areas characterized by the presence of karst terrains (Cesse catchment on Fig. 19a). According to Figure 19b, the timing of the water level peak on the Cesse River is rather different compared with the Ognon and Verdouble catchments during the November 1999 flood event. Two distinct water peak levels were recorded on the Cesse River, showing a significant lag time with the neighbouring catchments of the Argent-Double and Ognon. All three catchments were homogenously affected by the rainfall, but they reacted differently since only the Cesse catchment is influenced by karstic terrains.

Due to a dry autumn season, the karstic aquifers were almost empty at the beginning of November 1999. As a result, the cumulated rainfall triggered by the precipitation event directly infiltrated into the aquifer network. When the amount of water reached a specific threshold, some underground syphons were activated, leading to a sudden outflow. During the November 1999 event, the influence of the karstic aquifer and the subsequent late arrival of the Cesse flood waters dealt a final blow to the low-lying Aude floodplain and its inhabitants, where submersion had already occurred due to the breaching of dykes (Vinet, 2003). This can be considered as one of the factors explaining the remarkability of the flood event, reflecting the role played, firstly by the conjectured activation of underground syphons, and secondly by the structural control related to the geological features of the affected catchment area.

\subsubsection{Cascade effects associated with remarkable floods}


Recent flood events have highlighted the contribution of cascade effects in determining the hazard leading to a disaster. For example, most of the fatalities recorded during the Xynthia storm in February 2010 in France resulted from the role played by the overtopping of dykes. Because of their almost unpredictable character, and being linked to anthropogenic factors such as individual and societal response to the crisis, as well as natural features (spatio-temporal pattern and intensity of the hazard), cascade effects are rarely considered in risk management policies (Borga et al., 2011). Pointing out the influence of such effects requires a multidisciplinary approach, which we discuss here through four remarkable flood events.

\section{8 - Dyke breaching}

By reconstructing the flood chronology from documentary sources and assessing the damage for the city of Moissac during the March 1930 event, we find that dyke breaching is one of the key features determining the severity of the local flood hazard. According to Figure 20, most of the fatalities were recorded in the city centre. However, the city centre was flooded suddenly following three breaches on the railway embankment. Associated with an unusual flood duration (section 3.6.2), this flood led to several house collapses and many deaths. This fact stresses the significant effect of sudden submersion on flood fatalities and reveals the role played by structural failures during the process leading up to the hazard (Bonacci et al., 2006).

In the same way as with the March 1930 flood event, dyke breaching is also indicated as a key issue for the November 1999 flood event. In fact, several dyke breaches were recorded along the river network of the catchment area, leading to much damage. This was especially the case in the town of Sallèles d'Aude on the morning of $13^{\text {th }}$ November 1999. Under the pressure of flood waters aggravated by the accumulation of solid materials, the dyke along the Canal de Jonction was suddenly breached, leading to the destruction of the railway embankment located behind, which had already been destroyed during the March 1930 and October 1940 flood events (Lefrou et al., 2000), and the submersion of villages located downstream, where five fatalities occurred in Cuxac-d'Aude (Vinet, 2011).

\section{- Landslides}

Landslides are among the most damaging effects associated with flash floods. The compilation of multidisciplinary monographs on four remarkable floods revealed the impact of these phenomena on the remarkability evaluation process. Similarly as with dyke breaching, landslides (whose occurrence depends both on soil sensitivity and rainfall intensity) can play a significant role during the damaging process. For example, by collecting and analysing the circumstances of fatalities during the January 1980 flood event, we find that landslides were responsible for the half of the death toll attributable to the event (13 out of a total of 26). In particular, a massive landslide, reported in the centre of Réunion Island on $28^{\text {th }}$ of January, was responsible for the deaths of ten people in a family (Le Quotidien, 1980). In the same manner, five persons perished from a massive landslide in the Thore River valley during the November 1999 flood event. This assessment tends to confirm the significance of fast-moving mass failures such as landslides on mortality during natural disasters (Guzzetti et al., 2005).

While landslides represent a secondary hazard triggered by the rainfall event, they contribute directly to causing damage, and their occurrence also indirectly increases the flood hazard. During the October 1940 flood event, some wave effects were reported by the local inhabitants. These wave effects can be partly explained by the different phases of the rainfall event, characterized by several paroxysms, but also by the impact of several massive landslides reported during the event. Some of these landslides formed an obstruction on the floodplain, temporarily blocking the flow propagation. Under the effect of water pressure, some of these obstructions suddenly broke, leading to wave effects with significant consequences on damage. The effects due to breaching of these temporary dams should not be exaggerated in comparison with other parameters such as the rainfall intensity, but they nevertheless locally contributed significantly to 
Author-produced version of the article published in Journal of Hydrology (2016), vol. 54, part A, pp. 533-552

The original publication is available at http://www.sciencedirect.com, doi :10.1016/j.jhydrol.2016.05.032

C. This manuscript version is made available under the CC-BY-NC-ND 4.0 license

increasing the hazard level (Pardé, 1941). A final indirect effect associated with landslides is related to the increase in the transport of solid materials, as discussed below.

\section{- Solid transport}

A high rate of solid transport (including both sediment and drift wood) depends on two main parameters: the rainfall intensity, which partly determines the soil erodability, and the sensitivity of the catchment area itself. The sensitivity of the catchment area to solid transport is strictly related to its initial state at the time of the disaster and depends on both short and long-term factors. For example, the solid material transport capacity of a catchment area is partly determined by its characteristics such as the geological parameters, the slope and the exposition to intense rainfall events according to orographic processes. On the same line, this capacity is also linked to the flood history: a clustering of floods can either shorten/enhance the transportation of solid materials, depending on the stock of sediments along the river and catchment slopes. In the same way, solid transport is also impacted by anthropogenic factors. For example, such factors are considered in local river policies and especially those related to river management or the presence of structures that can contribute to increasing the quantity of solid materials carried by the flow. A case study related to the December 1947 and January 1948 flood events in the North-East of France showed that temporary wood bridges built after the Second World War were frequently involved in logjams and a local increase of flood hazard (Roubault et al., 1949).

The monographs about remarkable events show that solid transport is frequently involved in the processes leading to flood hazard. As mentioned previously, the occurrence of several landslides and the high concentrations of solid materials during the October 1940 event led to the destruction of a large amount of infrastructure. For this event, solid transport can also be identified as one of the causative factors leading to fatalities. Most of the 57 deaths were recorded at the place of habitation, generally swept away by the pressure of flood water flow according to eye-witness accounts. This was especially the case in the town of Amélie-les-Bains, which was completely transformed by the deposition of solid materials and where 13 deaths were reported (Ribes, 1982).

Similarly, the impact of solid transport is pointed out as one of the main factors responsible for the disaster following the January 1980 flood on Réunion Island. Due to the strong rainfall intensity and the high soil erosion rate on this island (Babonneau et al., 2013), many cases of landslides and a large amount of solid transport were reported. With regard to the exceptional duration of the precipitation triggered by cyclone Hyacinthe, a substantial amount of sediment carried by the flood flows was piled up on the downstream part of the ravine catchment areas (especially along the hydraulic structures, bridges and dykes). The deposition of this material slowed down the flow propagation and significantly raised the water level, leading to several dyke breaches and an unprecedented flood extent. Along the same lines, the contribution of solid transport due to the quantity of materials carried by the flow can also be noted as a decisive factor for the November 1999 flood event (Vinet, 2011).

\section{- Cascade effects at the cross-roads between social and natural sciences}

The significance of cascade effects in terms of damage and fatalities, including wave effects resulting from dyke breaching, needs to be linked to other parameters. For the 1930 flood event in Moissac, the fatalities were mainly concentrated in the city centre, highlighting the role of the sudden submersion due to dyke breaching. However, the dyke breaching has to be related with the risk management policies at the time of the disaster. As the city was suddenly flooded during the night of $2^{\text {nd }}$ to $3^{\text {rd }}$ March 1930 , without any effective warning process, the population was faced with an unexpected hazard. Furthermore, the large number of house collapses in Moissac not only depended on the hydrological hazard level but was also related to the typical regional housing made of raw brick, especially vulnerable to prolonged immersion. In the same way, we show that the contribution of solid transport can be directly linked with the flood 
chronology or land use management which determined the quantity of sediments available for transport. Furthermore, the example concerning the impact of solid transport on house collapses and fatalities during the October 1940 event must also be linked with the warning process at the time of the disaster. Finally, the cascade effects and their consequences appear to result from a combination of natural and anthropogenic agents that are difficult to separate, as well as their temporal evolution. Assessing the initial climatological features of the catchment is necessary to explain the impact of flash-flood precipitation on flood hazard. Moreover, it is essential to understand the anthropogenic development of the affected territory in order to identify the causative factors leading to remarkable flood events.

\section{Conclusion}

After a presentation of the methodology used to define flood remarkability, this study highlights the main factors involved in the process leading to four remarkable flood events.

On the one hand, characterizing the hydrometeorological hazard by means of indicators can give some idea of the level of hazard. The use of mapping stands out as an interesting tool to represent the different scale effects characterizing a past flood event and identify the triggering factors. For example, by producing a cross-plot of hazard indicators (such as the cumulated precipitation and return period of the peak discharge), we can highlight the correspondence between precipitation during a flood (depending on the synoptic situation) and the hydrological return period of the peak discharge during the October 1940 event. On the contrary, mapping the same indicators for the January 1980 event reveals that estimates of precipitation during a flood are insufficient for understanding the hydrological impacts. Some additional causes have to be explored. For example, we consider the role played by the initial state of the catchment area, which involves factors such as antecedent precipitation or the presence of snow cover at the time of the precipitation, which can contribute to increasing the hydrological hazard. This was especially the case during the March 1930 event. This example, characterized by an unusually late occurrence date, shows that it is necessary to consider the temporal evolution of the meteorological triggering event in order to assess the hazard. In the same way, the January 1980 event reveals that structural long-term factors such as the morphological parameters of the catchment area are also a key features determining the return period of the peak discharge. The rainfall intensity, even in exceptional cases, is only decisive for the flood hazard if there is a good correspondence with the response time of the impacted catchment area.

These different points shed some light on the complexity of the processes leading to remarkable flood events, which are defined by a combination of factors acting on different temporal and spatial scales. This aspect is also discussed by assessing the impact of cascade effects. Such phenomena, acting on a local scale and induced by the hydrometeorological hazard parameters, seem to have a significant and systematic influence during the process leading to the hazard. This is the case for dyke breaching (mentioned in 1930, 1980 and 1999), landslides (1940, 1980 and 1999) as well as solid transport (1940, 1980 and 1999). The analysis of cascade effects lies at the crossroads of natural and social sciences, so this type of multidisciplinary approach is important to improve our understanding of remarkable flood events, both from the point of view of hazard assessment as well as in relation to the material damage and impacts on society. In fact, the impact of cascade effects, especially when analysed in terms of the number of fatalities (Vinet, 2010), shows that flood hazard remains closely related to exposure and vulnerability. Bearing this in mind, the hazard of a remarkable flood event can be seen as resulting from a hybrid process, acting both on social and physical aspects. For example, the dyke breaching that occurred during the March 1930 event can be judged as a striking feature of the disaster, since the flood hazard was associated with sudden submersion as well as the specific vulnerability of the territory. The fatalities resulted primarily from several reported failures in the flood warning process, and secondly from numerous house collapses, themselves related to a vulnerable type 
Author-produced version of the article published in Journal of Hydrology (2016), vol. 54, part A, pp. 533-552

The original publication is available at http://www.sciencedirect.com, doi :10.1016/j.jhydrol.2016.05.032

C. This manuscript version is made available under the CC-BY-NC-ND 4.0 license

of housing. In the light of this example, short-term (dyke breaching, coincidence effects) and long-term factors (river development/hydraulic structures) can be identified as active during the process leading to the hazard. In the same way, short-term (failures of the warning process) and long-term factors (housing vulnerability, risk policies), which are more closely linked to social aspects, can be observed throughout the damaging process of a remarkable flood event.

In this way, hazard analysis shows that a multitude of scenarios - rather than any single situation - can lead to a remarkable flood event. This highlights the difficulty of performing a comparative analysis: a flood event should be considered as a singular event, associated with specific temporal and spatial scales, so it is hardly reproducible (Dourlens, 2003). A similar event in terms of hazard occurring at the present day would in fact lead to completely different impacts. For example, Boudou et al. (2016) showed that the occurrence of a flood at Moissac similar to the event of March 1930 would lead to different consequences, given that flood exposure and flood vulnerability have significantly changed in the meantime. However, retrospective and comparative analyses can be used to characterize the main causative factors and temporal evolution involved in past disasters. This approach is crucial for scientists and risk managers to anticipate the impact of future major flood events.

Finally, our analysis allows an assessment of the criteria used to define flood intensity during the establishment of the evaluation grid described in Section 2. Firstly, we show that the return period of the hazard is a helpful indicator to assess the flood intensity and is especially useful in hazard analysis through mapping. Secondly, the example of cyclone Hyacinthe reveals that duration of submersion can directly influence the assessment of flood hazard and remarkability, including in the case of floods resulting from heavy rainfall events, thus highlighting the pertinence of this indicator. Finally, we demonstrate that factors aggravating the hazard can be regarded as acting during the process leading to the hazard, and often contribute to generating significant damage. Our study also stresses the significance of additional factors such as the initial conditions of the catchment area or the spatio-temporal features of the hazard. However, these factors are difficult to integrate into a classification scale such as presented here. Further research along these lines could be conducted to integrate these additional factors into the evaluation grid.

\section{Acknowledgements}

The authors are especially grateful to Jean-Michel Soubeyroux and Annick Aufray from Météo-France for providing the data set used to characterize the rainfall data for the flood events. We would like to thank the members of the DDTM 11 for the supplementary information on the November 1999 event and François Gazelle for providing interesting information concerning the March 1930 flood event. Finally, special thanks are due to Laurie Caillouet and Eric Sauquet (IRSTEA) who helped to collate the rainfall data, which considerably simplified our work. The study was undertaken through the $\mathrm{PhD}$ research of Martin Boudou (2012-2015), with the financial support of the French Ministry of Ecology, Sustainable Development and Energy (MEDDE). Michael Carpenter post-edited the English style and grammar.

\section{References}

Antoine, J.-M., Desailly, B., Gazelle, F., 2001. Les crues meurtrières, du Roussillon aux Cévennes. Annales de Géographie, 110(622): 597-623.

Babonneau, N., Delacourt, C., Cancouët, R., Sisavath, E., Bachelery, P., Mazuel, A., Jorry, S.J., Deschamps, A., Ammann, J., Villeneuve, N., 2013. Direct sediment transfer from land to deep-sea: Insights into shallow multibeam bathymetry at La Réunion Island. Marine Geology, 346: 47-57.

Battle, M., Gual, R., 1981. 1940 L'Aiguat: les inondations de 1940. Terra Nostra, Revista Escolar Catalana, 42: 206. 
Boissier, L., 2013. La mortalité liée aux crues torrentielles dans le Sud de la France: une approche de la vulnérabilité humaine face à l'inondation, PhD, Université Paul Valéry-Montpellier III, Montpellier, 215p.

Bonacci, O., Ljubenkov, I., Roje-Bonacci, T., 2006. Karst flash floods: an example from the Dinaric karst (Croatia). Natural Hazards and Earth System Science, 6(2): 195-203.

Borga, M., Anagnostou, E., Blöschl, G., Creutin, J.-D., 2011. Flash flood forecasting, warning and risk management: the HYDRATE project. Environmental Science \& Policy, 14(7): 834-844.

Borga, M., Boscolo, P., Zanon, F., Sangati, M., 2007. Hydrometeorological analysis of the 29 August 2003 flash flood in the Eastern Italian Alps. Journal of Hydrometeorology, 8(5): 1049-1067.

Boudou, M., 2015. Approche multidisciplinaire pour la caractérisation d'inondations remarquables : enseignements tirés de neuf évènements en France (1910-2010). PhD, Irstea - Lyon, Université PaulValéry Montpellier III, Montpellier, 463 p. + 450 p. (annexes).

Boudou M., Cœur D., Lang M., Vinet F., 2015. Grille de lecture pour la caractérisation d'évènements remarquables d'inondations en France : exemple d'application pour la crue de mars 1930 dans le bassin de la Garonne et du Tarn. In « Environnement, politiques publiques et pratiques locales », Ed. L'Harmattan du livre, 311-336.

Boudou M., Danière B., Lang M., 2016. Assessing changes in urban flood vulnerability through mapping land use from historical information. HESS, 20, 161-173, doi:10.5194/hess-20-161-2016

Brazdil, R., Kundzewicz, Z.W., Benito, G., 2006. Historical hydrology for studying flood risk in Europe. Hydrological Sciences Journal, 51(5): 739-764. DOI:10.1623/hysj.51.5.739

Burn, D.H., 1999. Perceptions of flood risk: a case study of the Red River flood of 1997. Water Resour. Res., 35(11): 3451-3458.

Calianno, M., Ruin, I., Gourley, J.J., 2013. Supplementing flash flood reports with impact classifications. Journal of Hydrology, 477(0): 1-16. doi:10.1016/j.jhydrol.2012.09.036

Chauvière, J.Y., Lafitte, J.J., Le Quentrec, M., Ravard, J.L., Truchot, C., Verdeaux, P., 2010. Prévisions des crues et hydrométrie : évaluation des réseaux et perspectives, $n^{\circ} 005620-01$. Ministère de l'Ecologie, de l'Energie, du Développement durable et de la Mer, www.cgedd.developpement-durable.gouv.fr, 129 p.

Cœur, D., 2008. La maîtrise des inondations dans la plaine de Grenoble (XVIIe-XXe siècle) : enjeux techniques, politiques et urbains. PhD, Univ. Grenoble 2, Ed. Quae, Versailles, 310p.

Compo, G.P., Whitaker, J.S., Sardeshmukh, P.D., Matsui, N., Allan, R.J., Yin, X., Gleason, B.E., Vose, R., Rutledge, G., Bessemoulin, P., 2011. The twentieth century reanalysis project. Quarterly Journal of the Royal Meteorological Society, 137(654): 1-28.

Creutin, J.-D., M. Borga, E. Gruntfest, C. Lutoff, D. Zoccatelli, and I. Ruin, 2013: A space and time framework for analysing human anticipation of flash floods. Journal of Hydrology, 482, 14 - 24, doi:10.1016/j.jhydrol.2012.11.009.

Creutin J.D., Borga M., Lutoff C., Scolobig A., Ruin I., Creton-Cazanave L. - 2009 - Catchment dynamics and social response during flash floods: the potential of radar rainfall monitoring for warning procedures Meteorological Applications : 16, 115-12.

de Moel, H., Alphen, J.v., Aerts, J., 2009. Flood maps in Europe-methods, availability and use. Natural Hazards and Earth System Science, 9(2): 289-301.

Delrieu, G., Ducrocq, V., Gaume, E., Nicol, J., Payrastre, O., Yates, E., Kirstetter, P.E., Andrieu, H., Ayral, P.A., Bouvier, C., Creutin, J.D., Livet, M., Anquetin, S., Lang, M., Neppel, L., Obled, C., Parent-duChatelet, J., Saulnier, G.M., Walpersdorf, A., Wobrock, W., 2005. The catastrophic flash-flood event of 8-9 September 2002 in the Gard region, France: A first case study for the Cevennes-Vivarais Mediterranean Hydrometeorological Observatory. Journal of Hydrometeorology, 6(1): 34-52. doi:10.1175/jhm-400.1

Direction de la Météorologie, 1980. Saison cyclonique 1979-1980 République Française, Ministère des Transports, Saint-Denis de la Réunion, 19p. 
Dougados, J., Gaussen, H., 1930. Les inondations de mars 1930 dans le Sud-Ouest de la France et leurs conditions météorologiques. Bulletin de la société d'histoire naturelle de Toulouse, Tome 54: 208-222.

Dourlens, C., 2003. La question des inondations au prisme des sciences sociales. CERPE, Ministère de l'Equipement, des Transports et du Logement (DRAST), 102 p.

Drobinski, P., Ducrocq, V., Alpert, P., Anagnostou, E., Béranger, K., Borga, M., Braud, I., Chanzy, A., Davolio, S., Delrieu, G., 2014. HyMeX: a 10-year multidisciplinary program on the mediterranean water cycle. Bulletin of the American Meteorological Society, 95(7): 1063-1082.

Gaume, E., Bain, V., Bernardara, P., Newinger, O., Barbuc, M., Bateman, A., Blaškovičová, L., Blöschl, G., Borga, M., Dumitrescu, A., 2009. A compilation of data on European flash floods. Journal of Hydrology, 367(1): 70-78.

Gaume, E., Livet, M., Desbordes, M., Villeneuve, J.P., 2004. Hydrological analysis of the river Aude, France, flash flood on 12 and 13 November 1999. Journal of Hydrology, 286(1-4): 135-154. doi:10.1016/j.jhydrol.2003.09.015.

Gaume E., Payrastre O., Degoutte G., 2015. Recherche historique et reconstitution de la crue de 1940 sur les bassins versants de la Têt et du Tech. Rapport d'étude, Direction départementale des Territoires et de la Mer des Pyrénées Orientales, nov., 82 p.

Guzzetti, F., Stark, C.P., Salvati, P., 2005. Evaluation of flood and landslide risk to the population of Italy. Environmental Management, 36(1): 15-36.

Humbert, M., Bargeas, A., 1986. Erosion, drainage des eaux superficielles et inondations torrentielles à l'Entre-Deux (Île de la Réunion). BRGM, 35 p.

Jonkman, S.N., 2005. Global perspectives on loss of human life caused by floods. Natural hazards, 34(2): 151-175. doi:10.1007/s11069-004-8891-3

Kundzewicz, Z.W., Pińskwar, I., Brakenridge, G.R., 2013. Large floods in Europe, 1985-2009. Hydrological Sciences Journal, 58(1): 1-7. doi:10.1080/02626667.2012.745082

Lambert, R., 1991. Le fond de l'eau, Le Tarn, mémoire de l'eau, mémoires des hommes, Toulouse, 41-63.

Lang, M., Coeur, D., Bard, A., Bacq, B., Becker, T., Bignon, E., Blanchard, R., Bruckmann, L., Delserieys, M., Edelblutte, C., Merle, C., 2012. Preliminary Flood Risk Assessment for the European Directive: inventory of French past floods, Comprehensive Flood Risk Management. Taylor and Francis group, Rotterdam, NLD, 1211-1217.

Le Quotidien, 1980. Dossier «La Tragédie Hyacinthe », Journal Le Quotidien, Bibliothèque Départementale de La Réunion, 48p.

Lefrou, C., Martin, X., Labarthe, J.-P., Varret, J., Mazière, B., Tordjeman, R., Feunteun, R., 2000. Les crues des 12, 13 et 14 novembre 1999 dans les départements de l'Aude, de l'Hérault, des Pyrénées-Orientales et du Tarn. Rapport technique, Ministère de l'Aménagement du Territoire et de l'Environnement, Inspection Générale de l'Environnement, 140p.

Llasat, M.d.C., 2004. La vulnérabilité en Catalogne et la perception sociale. La Houille Blanche, 6, 71-75.

Llasat, M.d.C ., Barriendos, M., Barrera, A., Rigo, T., 2005. Floods in Catalonia (NE Spain) since the 14th century. Climatological and meteorological aspects from historical documentary sources and old instrumental records. Journal of hydrology, 313(1): 32-47.

Llasat Botija, M.d.C., Llasat-Botija, M., López, L., 2009. A press database on natural risks and its application in the study of floods in Northeastern Spain. Natural Hazards and Earth System Sciences, 2009, 9, 2049-2061.

Marchi, L., Borga, M., Preciso, E., Gaume, E., 2010. Characterisation of selected extreme flash floods in Europe and implications for flood risk management. Journal of Hydrology, 394(1-2): 118-133. DOI:10.1016/j.jhydrol.2010.07.017

Mayoka, M., 1998. Les cyclones tropicaux à la Réunion Direction interrégionale de Météo-France à la Réunion, Saint-André (La Réunion), 48 p. 
Merz, B., Hall, J., Disse, M., Schumann, A., 2010a. Fluvial flood risk management in a changing world. Natural Hazards and Earth System Science, 10(3): 509-527.

Merz, B., Kreibich, H., Schwarze, R., Thieken, A., 2010b. Assessment of economic flood damage. Natural Hazards and Earth System Science, 10(8): 1697-1724.

Messner, F., Meyer, V., 2006. Flood damage, vulnerability and risk perception-challenges for flood damage research. Springer, $27 \mathrm{p}$.

Météo-France, 1999. Estimation des hauteurs de précipitations d'occurrence rare pour des durées de cumul de 1 à 10 jours sur 3000 postes français, méthode de renouvellement, rapport d'élaboration, $\mathrm{n}^{\circ}$ CBDHYED00374. Service Central d'Exploitation de la Météorologie, Division Climatologie et Bases de données, $463 \mathrm{p}$.

Neppel, L., Desbordes, M., Montgaillard, M., 2001. Fréquence de l'épisode pluvieux à l'origine des inondations des 12 et 13 novembre 1999 dans l'Aude. Comptes Rendus de l'Académie des Sciences Series IIA - Earth and Planetary Science, 332(4): 267-273. doi:http://dx.doi.org/10.1016/S12518050(01)01527-0

Pardé, M., 1930. La crue de mars 1930 dans le sud et le sud-ouest de la France : Genèse de la catastrophe. Revue Géographique des Pyrénées et du sud-ouest, T n ${ }^{\circ} 1$ fasc. IV: 353-459.

Pardé, M., 1941. La formidable crue d'octobre 1940 dans les Pyrénées-Orientales. Revue géographique des Pyrénées et du Sud-Ouest, 12: 237-279.

Parker, D.J., 2000. Floods. Routledge, London, 748 p.

Ribes, J., 1982. Tome 3 : Séisme et inondations, le cataclysme de 1940, Haut et moyen Vallespir au fil du temps. Editions Du Castillet, Perpignan, 190p.

Rogers, R., Marks, F., Marchok, T., 2009. Tropical cyclone rainfall. In: (Ed.), M.G.A. (Ed.), Encyclopedia of hydrological sciences, Chichester, UK:John Wiley \& Sons, Ltd. DOI:10.1002/0470848944.hsa030

Roubault, M., Brunotte, R., Frontard, J., Oudin, A., Sadran, G., 1949. Rapport de la commission d'étude technique des inondations de décembre 1947 dans le Bassin Lorrain, Préfecture de Meurthe-et-Moselle. Societé d'Impressions Typographiques, Nancy, 101p.

Ruin, I., Gaillard, J.-C., Lutoff, C., 2007. How to get there? Assessing motorists' flash flood risk perception on daily itineraries. Environmental hazards, 7(3): 235-244.

Ruin, I., Lutoff, C., Boudevillain, B., Creutin, J.-D., Anquetin, S., Bertran-Rojo M., Boissier, L., Bonnifait, L., Borga, M., Colbeau-Justin, L., Creton-Cazanave, L., Delrieu, G. Douvinet, J., Gaume, E., Gruntfest, E., Naulin J.-P., Payrastre O., Vannier, O. (2014) Social and hydrological responses to extreme precipitations: An interdisciplinary strategy for post-flood investigation - Weather, Climate and Society, Weather, Climate \& Society . 6(1), 135-153.

Ruiz-Bellet, J.L., Balasch, J.C., Tuset, J., Barriendos, M., Mazon, J., Pino, D., 2015. Historical, hydraulic, hydrological and meteorological reconstruction of 1874 Santa Tecla flash floods in Catalonia (NE Iberian Peninsula). J. Hydrology, 524, 279-295, dx.doi.org/10.1016/j.jhydrol.2015.02.023

Schröter, K., Kunz, M., Elmer, F., Mühr, B., Merz, B., 2015. What made the June 2013 flood in Germany an exceptional event? A hydro-meteorological evaluation. Hydrology and Earth System Sciences Discussions, 11(7): 8125-8166.

SwissRe, 2015. Natural catastrophes and man-made disaster in 2014: convective and winter storms generate most losses. Sigma, 2: 52.

Vinet, F., 2003. Crues et inondations dans la France méditerranéenne : les crues torrentielles des 12 et 13 novembre 1999 (Aude, Tarn, Pyrénées-Orientales, Hérault). Questions de géographie. Editions du Temps, Nantes, 224 p.

Vinet, F., 2008. Geographical analysis of damage due to flash floods in southern France: The cases of 12-13 November 1999 and 8-9 September 2002. Applied Geography, 28(4): 323-336.

Vinet, F., 2010. Le risque inondation : Diagnostic et gestion. Éditions Tec \& doc, Monts, 314 p. 
1 Vinet, F., 2011. Flood Risk Assessment and Management in France. The Case of Mediterranean Basins. 2 Flood Prevention and Remediation. WIT Press. Southampton, UK: 105-132.

3 Vinet, F., Lumbroso, D., Defossez, S., Boissier, L., 2012. A comparative analysis of the loss of life during two recent floods in France: the sea surge caused by the storm Xynthia and the flash flood in Var. Natural hazards, 61(3): 1179-1201. 

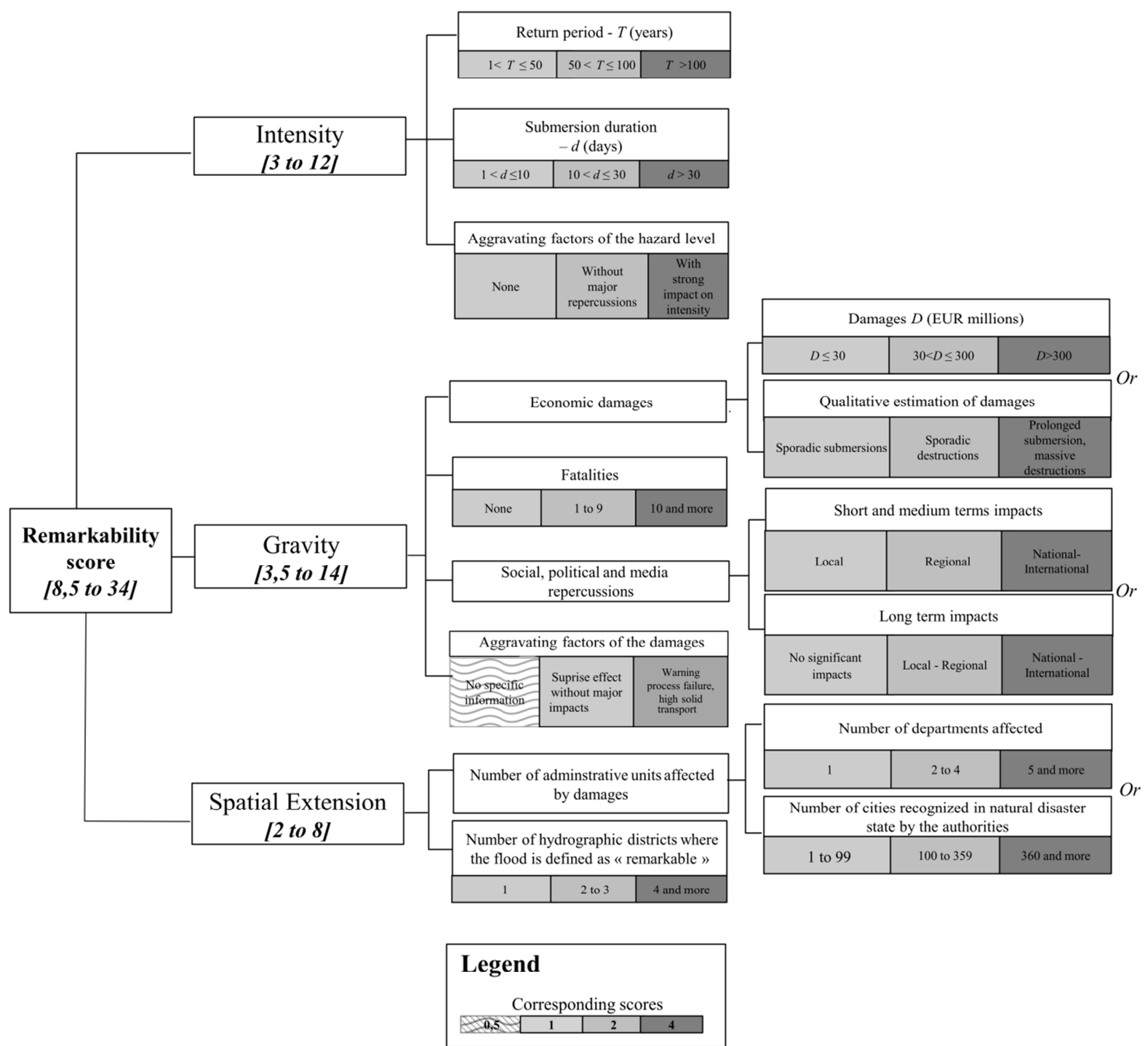

Figure 1. Model of the evaluation grid 


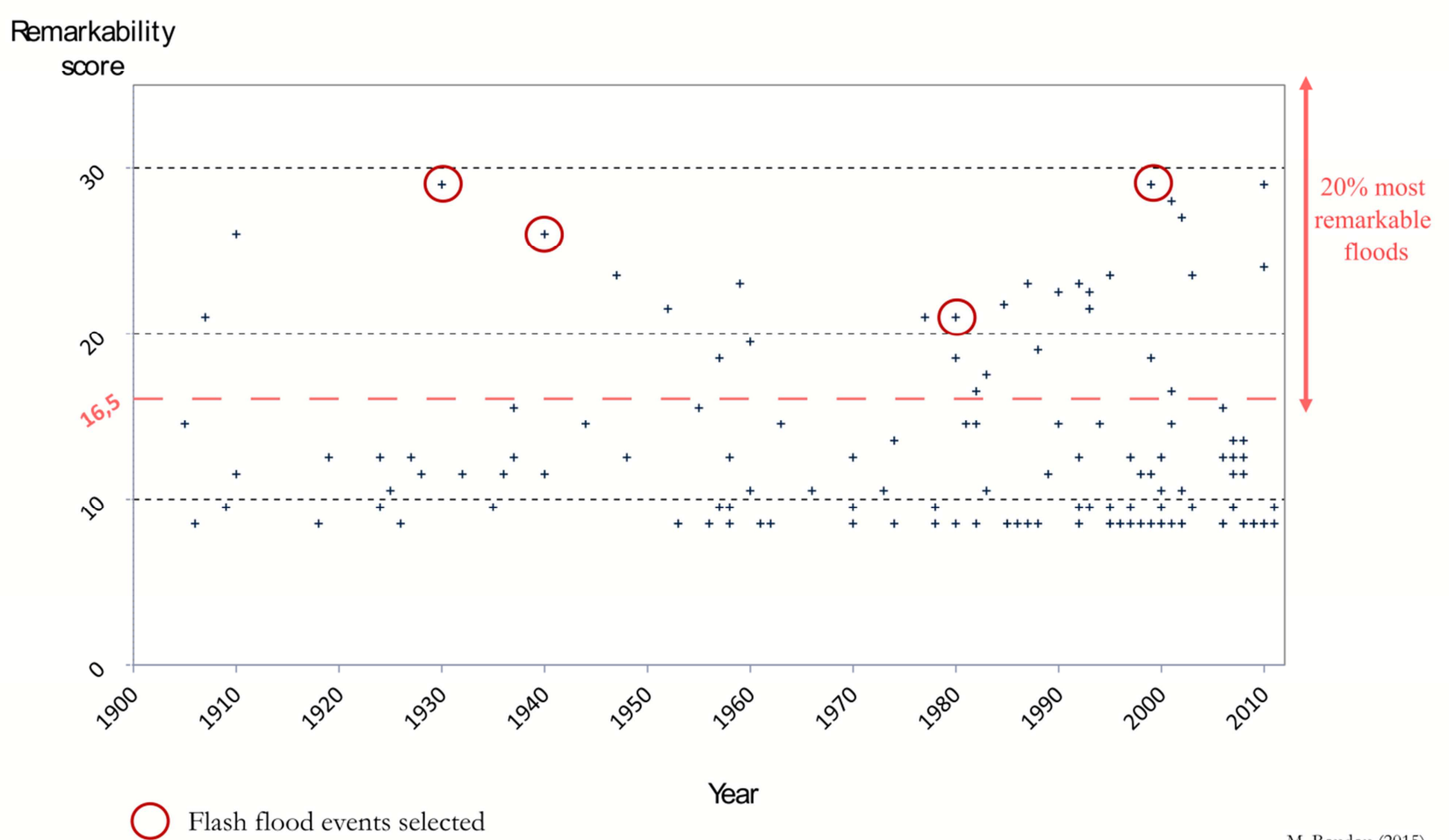

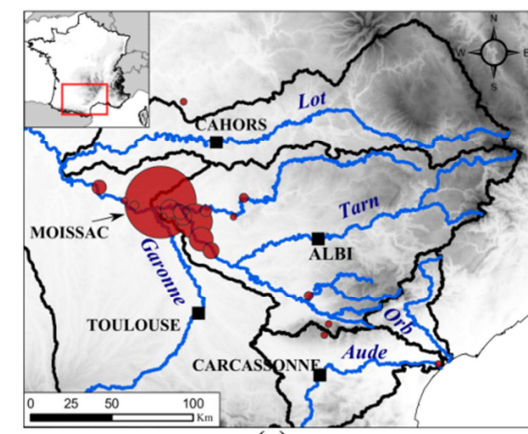

(a)

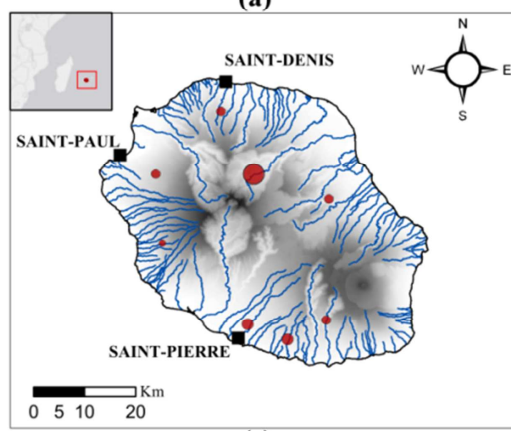

(c)

Legend

Fatalities

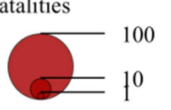

$\frown$ Main rivers affected

\section{Figure 2. Application of the evaluation grid on 140 flood events from the French PFRA, which took place} after 1900

Figure 3. Location map and fatalities of the 4 flash flood events: (a) March 1930; (b) October 1940; (c) January 1980; (d) November 1999 
Author-produced version of the article published in Journal of Hydrology (2016), vol. 54, part A, pp. 533-552

The original publication is available at http://www.sciencedirect.com, doi :10.1016/j.jhydrol.2016.05.032

(c. This manuscript version is made available under the CC-BY-NC-ND 4.0 license

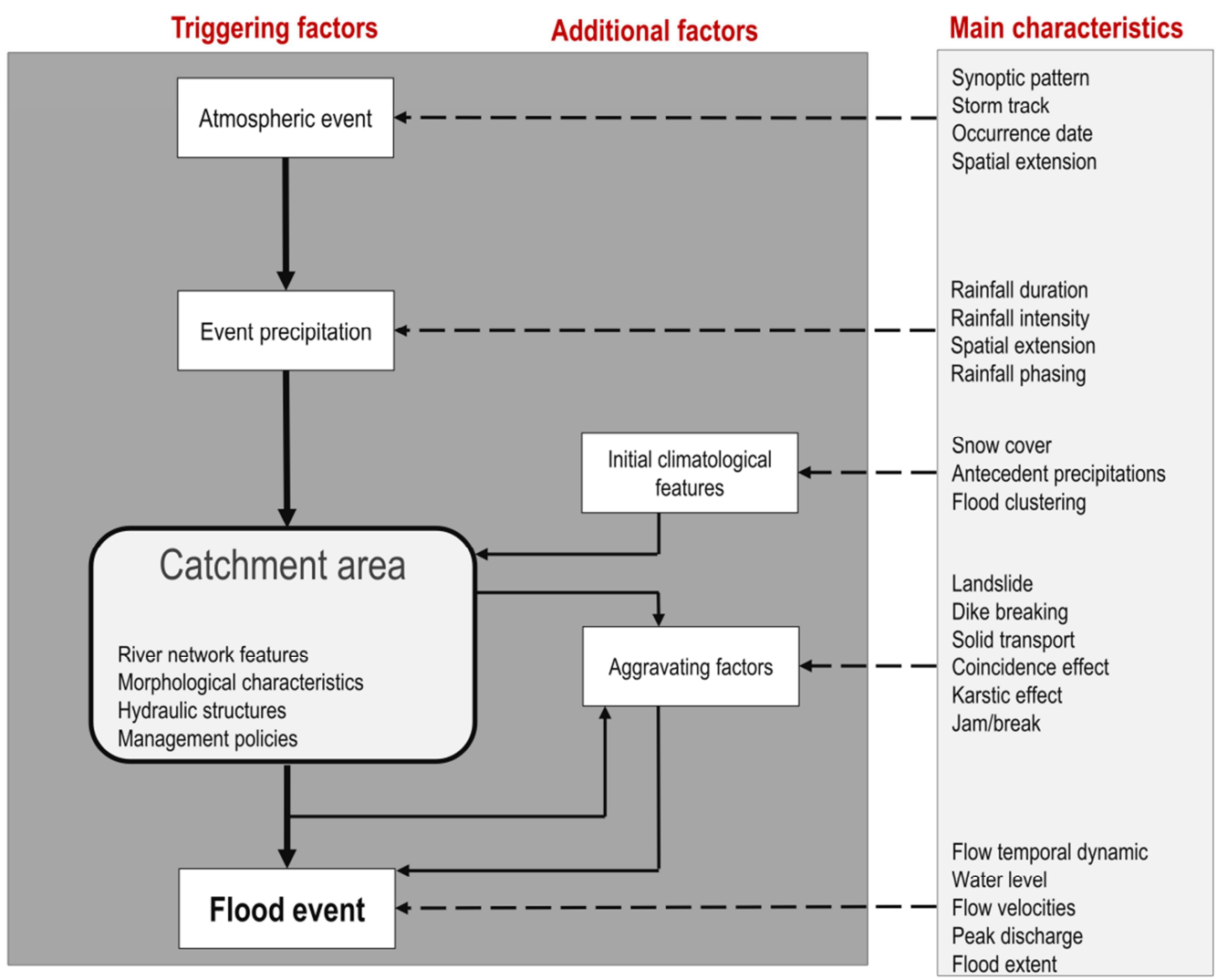

Figure 4. Causal graph of the hazard process leading to a remarkable flash flood event

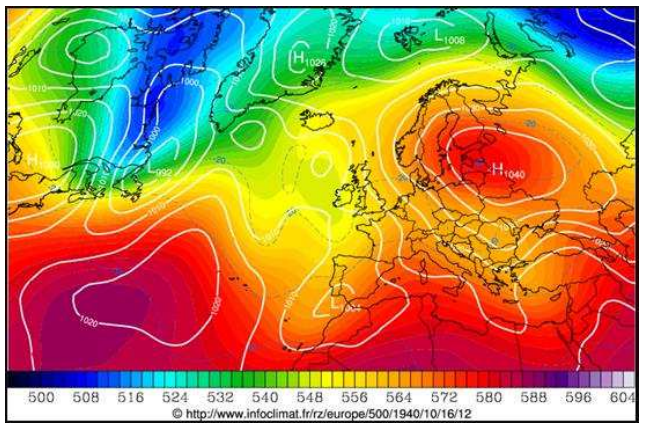

Figure 5. Geopotential 500 Hpa of the 16th October 1940 from 20Cr Reanalysis (www.infoclimat.fr/) 


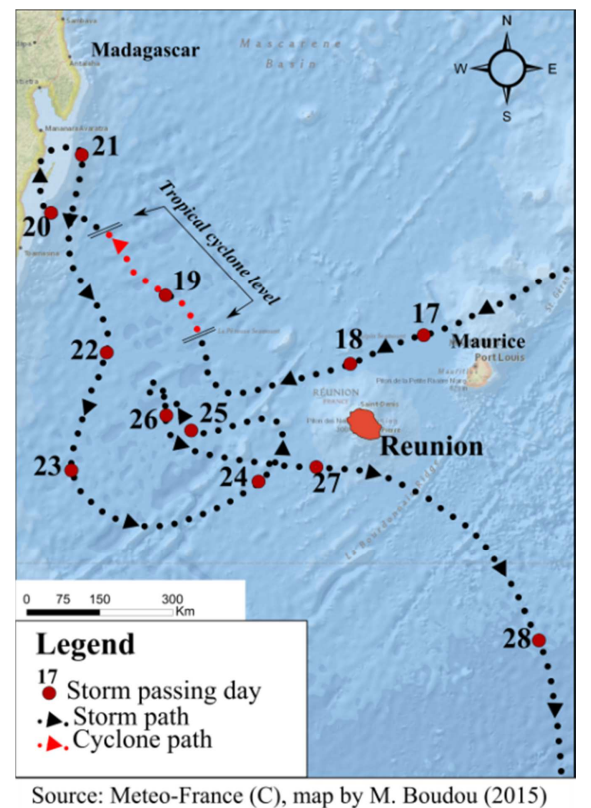

Figure 6. Storm path of the Hyacinthe cyclone (January 1980)

\begin{tabular}{|c|c|c|c|c|}
\hline Flood event & $\begin{array}{l}\text { Maximum daily rainfall in } \mathrm{mm} \\
\text { (date) }\end{array}$ & Rain gauge & $\begin{array}{l}\text { Maximum total rainfall in } \\
\mathrm{mm} \text { (event duration) }\end{array}$ & Rain gauge \\
\hline March 1930 & $\begin{array}{c}192 \\
(01 / 03 / 1930)\end{array}$ & $\begin{array}{l}\text { Saint-Gervais-sur-Mare } \\
\text { (Hérault) }\end{array}$ & 694 (7 days) & $\begin{array}{l}\text { Saint-Gervais-sur-Mare } \\
\text { (Hérault) }\end{array}$ \\
\hline October 1940 & $\begin{array}{c}\sim 1000 \\
(17 / 10 / 1940)\end{array}$ & $\begin{array}{l}\text { Saint-Laurent-de-Cerdans } \\
\text { (Pyrénées-Orientales) }\end{array}$ & 1930 (4 days) & $\begin{array}{l}\text { Saint-Laurent-de-Cerdans } \\
\text { (Pyrénées-Orientales) }\end{array}$ \\
\hline January 1980 & $\begin{array}{c}1742 \\
(26-27 / 01 / 1980)\end{array}$ & Grand-Ilet (Reunion) & $\mathbf{6 0 5 1}$ (12 days) & Commerson (Reunion) \\
\hline November 1999 & $\begin{array}{c}551 \\
(12 / 11 / 1999)\end{array}$ & $\begin{array}{l}\text { Lezignan-Corbieres } \\
\qquad(\text { Aude })\end{array}$ & 624 (2 days) & $\begin{array}{l}\text { Lezignan-Corbieres } \\
\qquad(\text { Aude })\end{array}$ \\
\hline
\end{tabular}



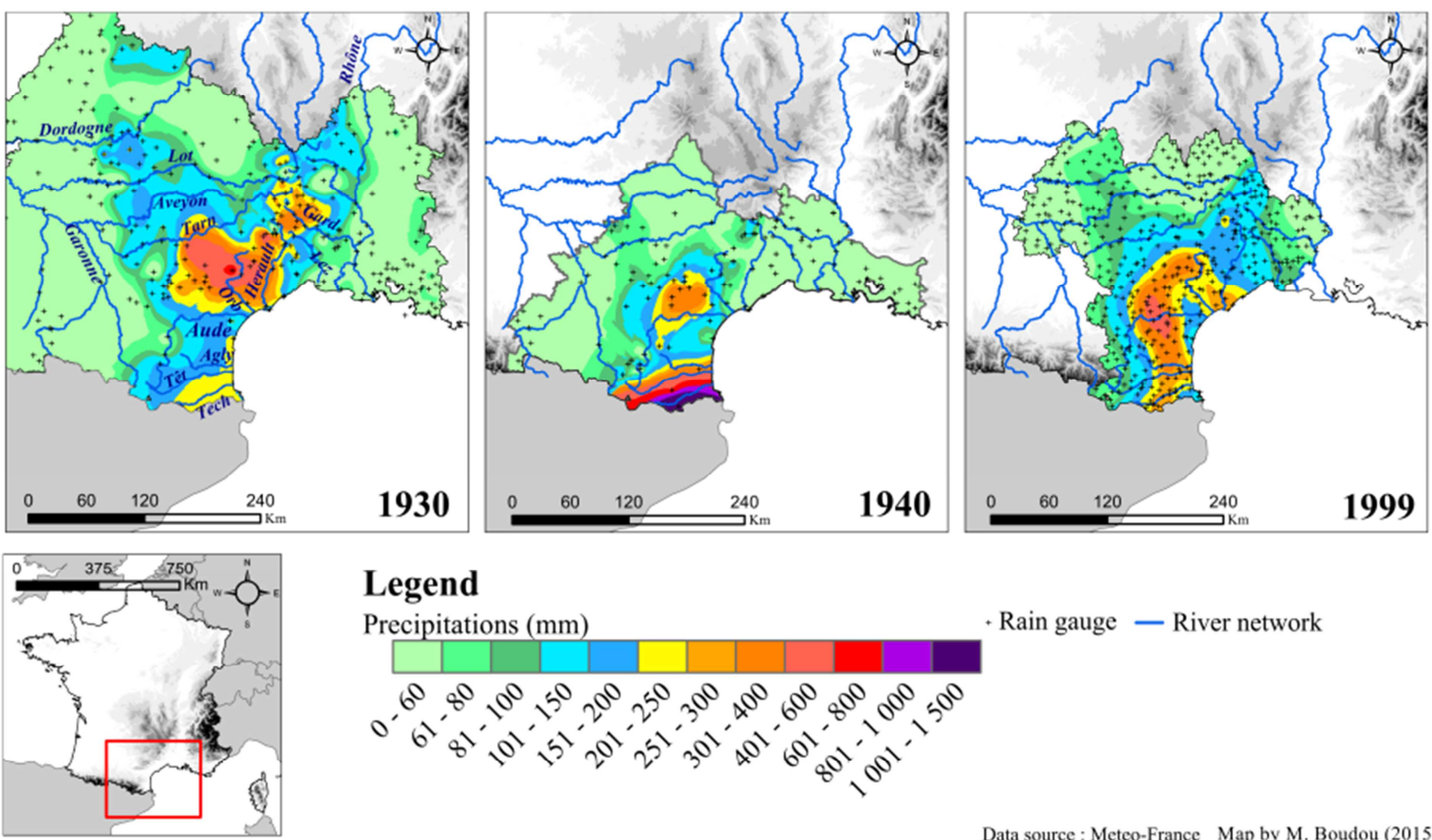

\section{Legend}

Precipitations $(\mathrm{mm})$

Rain gauge - River network

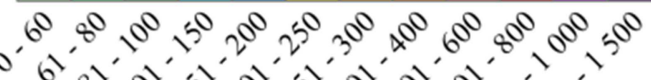

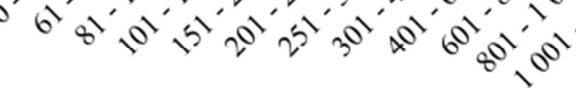

Data source : Meteo-France Map by M. Boudou (2015)

Figure 7. Spatial field of the event precipitation during 3 Mediterranean flash flood events: March 1930 (5 days), October 1940 (4 days), November 1999 (2 days)

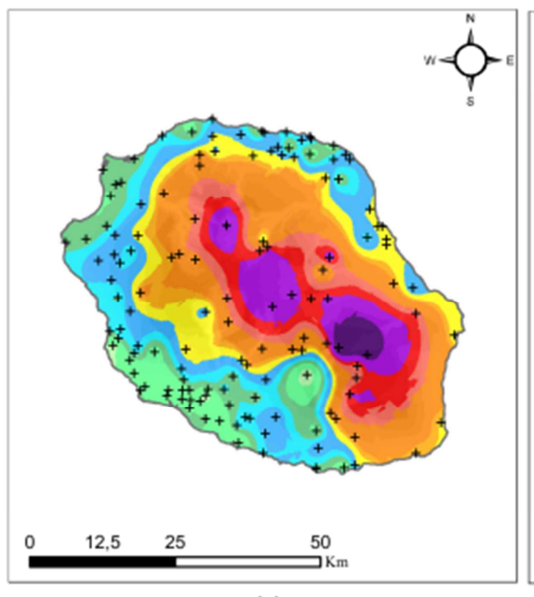

(a)

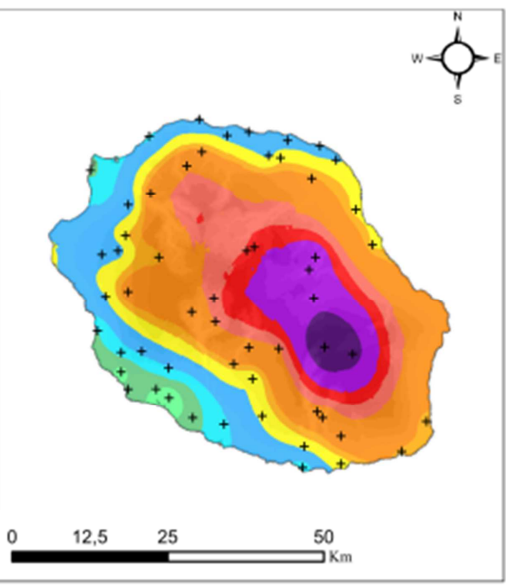

(b)

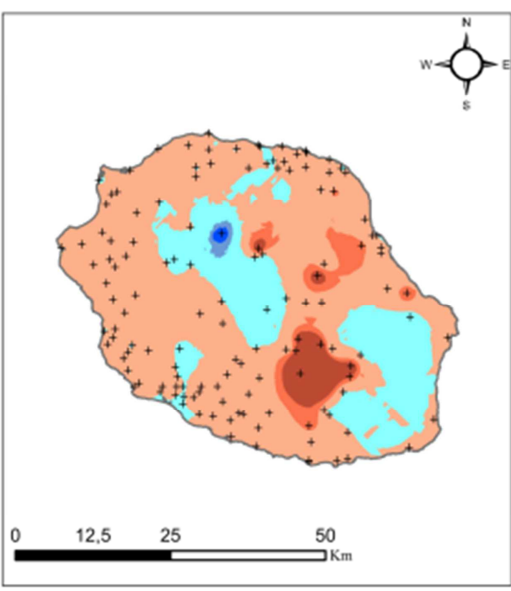

(c)

Legend

Total rainfall (mm) January 15-28, 1980

Difference of precipitations $(\mathrm{mm})+$ Rain gauge
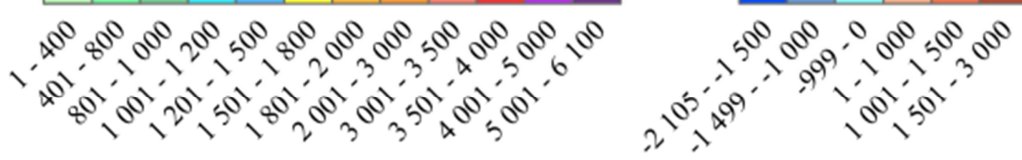

Data source : Meteo-France. Map by M. Boudou (2015)

Figure 8. Impact of the rain gauge network density on mapping the rainfall field for the January 1980 Hyacinthe cyclone on Réunion Island: (a) 136 rain gauges; (b) 57 rain gauges; (c) difference of precipitations $(b)-(a)$ 


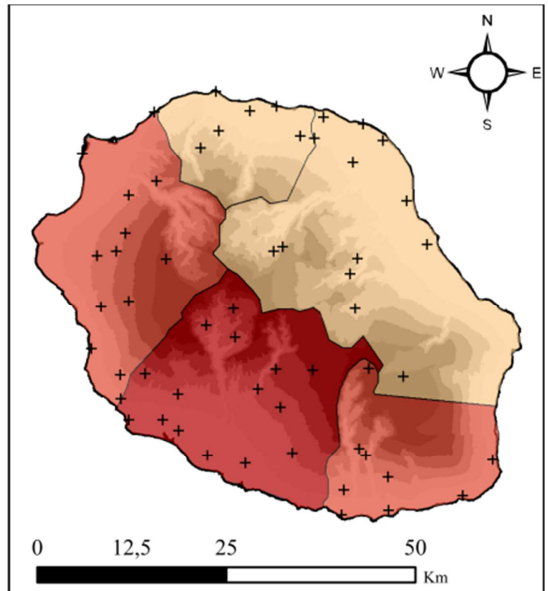

Figure 9. Ratio of the event precipitations to the interannual mean of January (1981-2010)

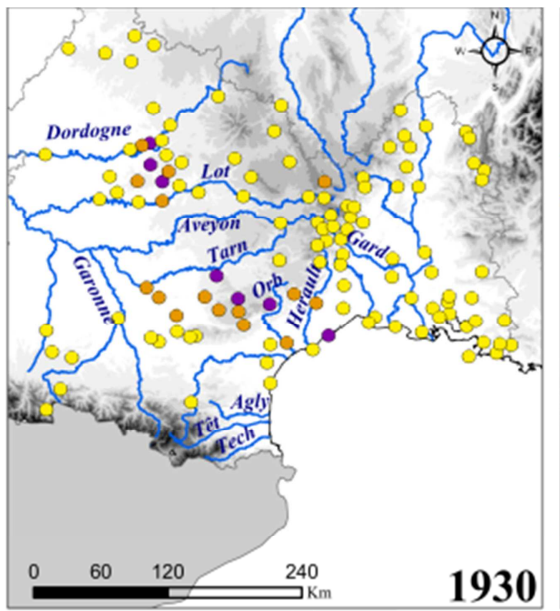

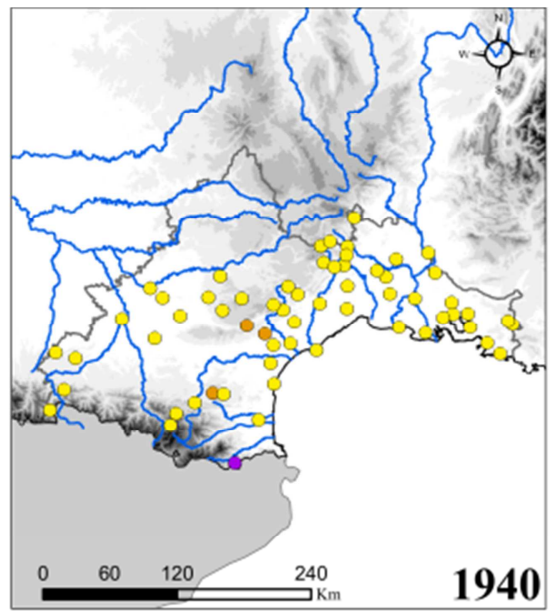

(b)

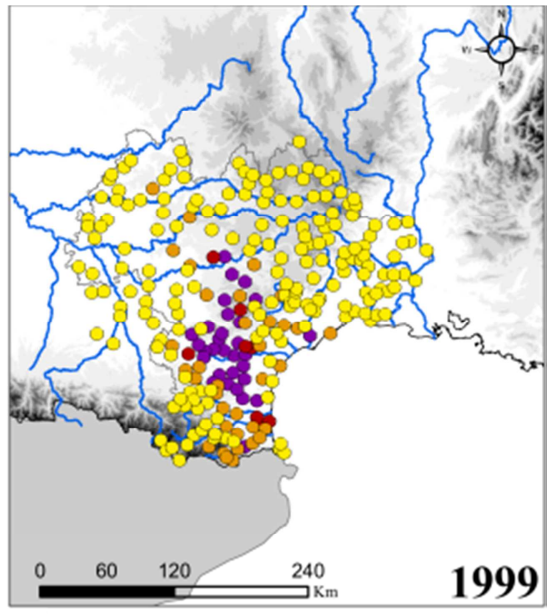

(c)

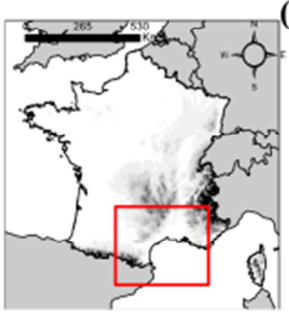

Legend

Return period $\mathrm{T}$ (years) of the precipitations

$\mathrm{T} \leqslant 10$

- $10<\mathrm{T} \leqslant 50$

$\frown$ River network

- $50<\mathrm{T} \leqslant 100$

- $\mathrm{T}>100$

Data source: Meteo-France. Map by M. Boudou (2015)

Figure 10. Local return period of the rainfall event: (a) 1930 (26 February - 3 March); (b) 1940 (17-20 October); (c) 1999 (12-13 November) 


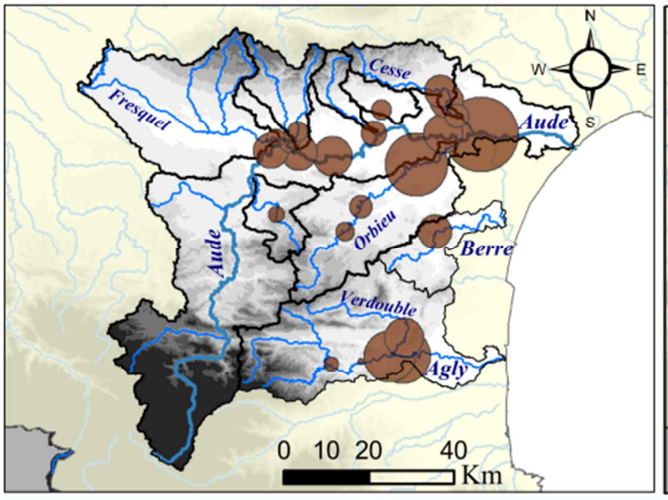

(a)

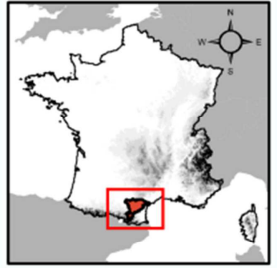

Legend

$\square$ Catchment area

$\frown$ Rivers network

Elevation (meters)

${ }_{3} 0^{\circ}$

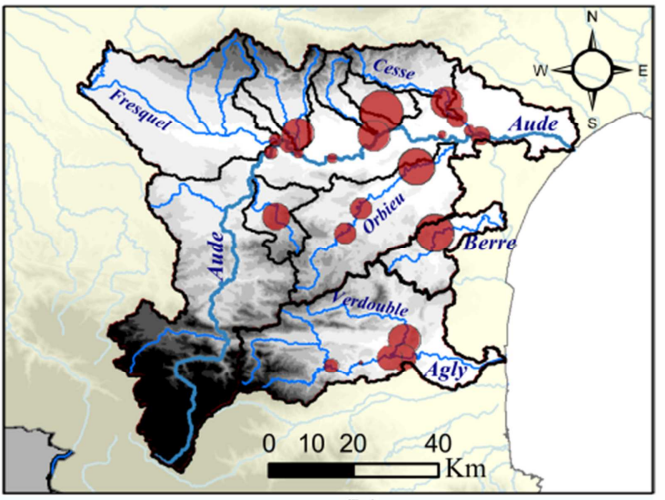

(b)

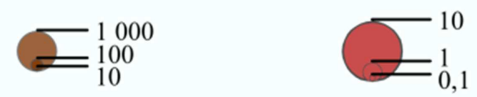

Map by M. Boudou (2015)

Figure 11. November 1999 flood event: (a) peak discharge; (b) specific peak discharge

3

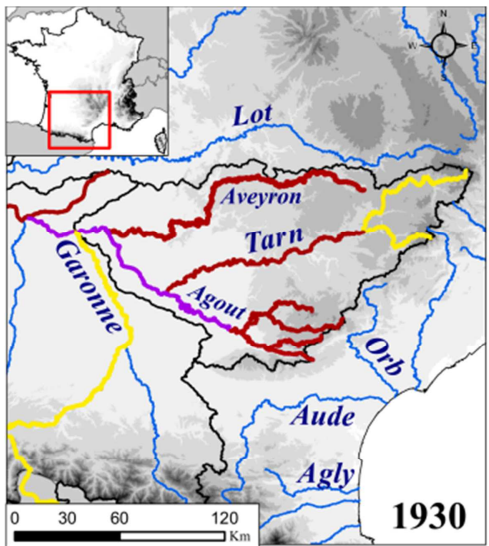

Legend (a)

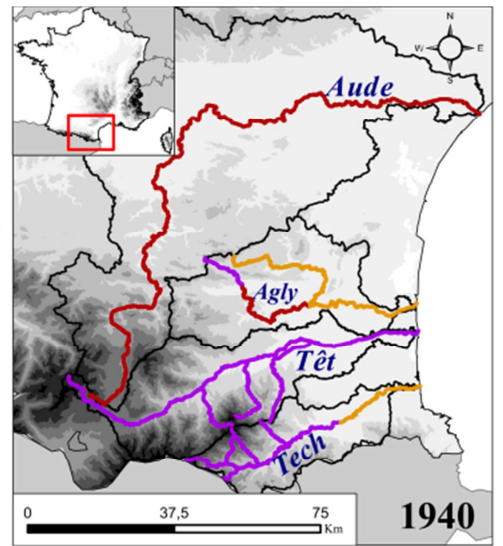

(b)

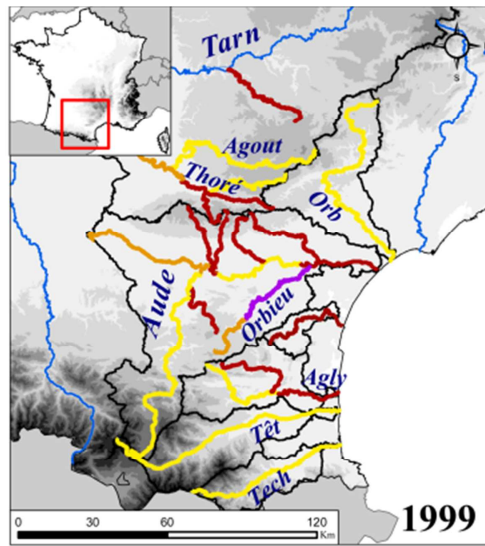

(c)

Return period $\mathrm{T}$ (years) of the peak discharge

$\mathrm{T} \leqslant 10$

Catchment area

Elevation (meters)

$\frown 10<\mathrm{T} \leqslant 50$

$\frown$ Non-affected rivers or no discharges data

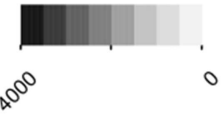

$\frown 50<\mathrm{T} \leqslant 100$

Map by M. Boudou (2015)

Figure 12. Return period of the peak discharge: (a) March 1930; (b) October 1940; (c) November 1999 
4

\section{Legend}

-. $800 \mathrm{~mm}$ isohyet

- Gauging station

Catchment area

Non-affected river or no discharge data

Return period $\mathrm{T}$ (years) of the peak discharge

$\mathrm{T} \leqslant 10$

$\frown 10<\mathrm{T} \leqslant 50$

$\frown 50<\mathrm{T} \leqslant 100$

$\frown \mathrm{T}>100$

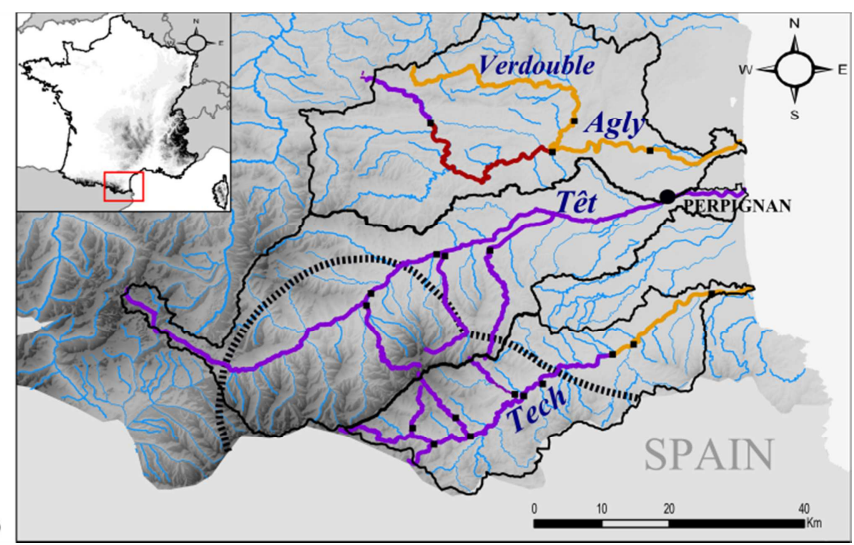

Figure 13. Cross-representation between the return period of peak discharge and precipitations over 800 mm (17-20 October 1940)

\section{Legend}

$+*$ Isohyet line

$(\mathrm{mm})$

Flood extent

Non-affected river
or no discharge data

Return period $\mathrm{T}$ (years)

of the peak discharge

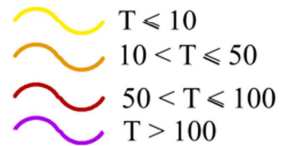

Map by M. Boudou (2015)

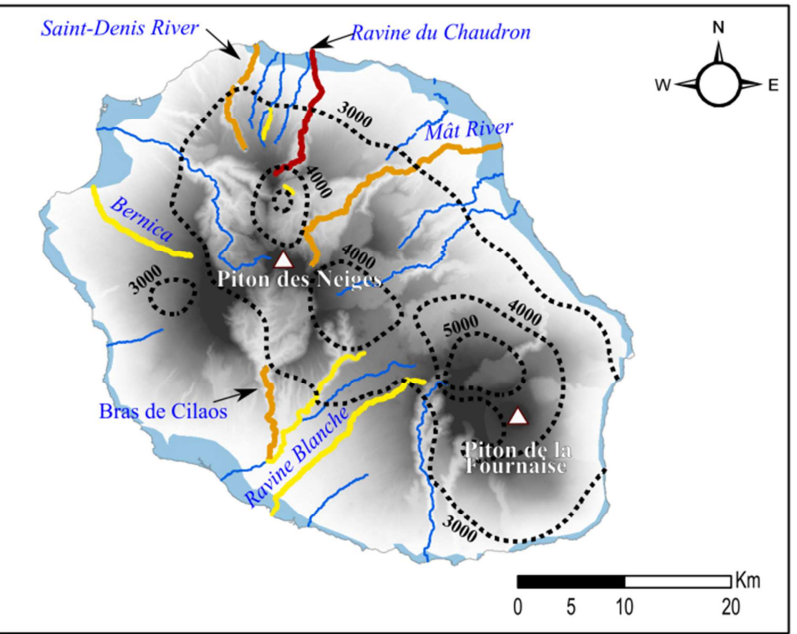

Figure 14. Cross-representation between the return periods of peak discharge and precipitations (15-28 January 1980) 


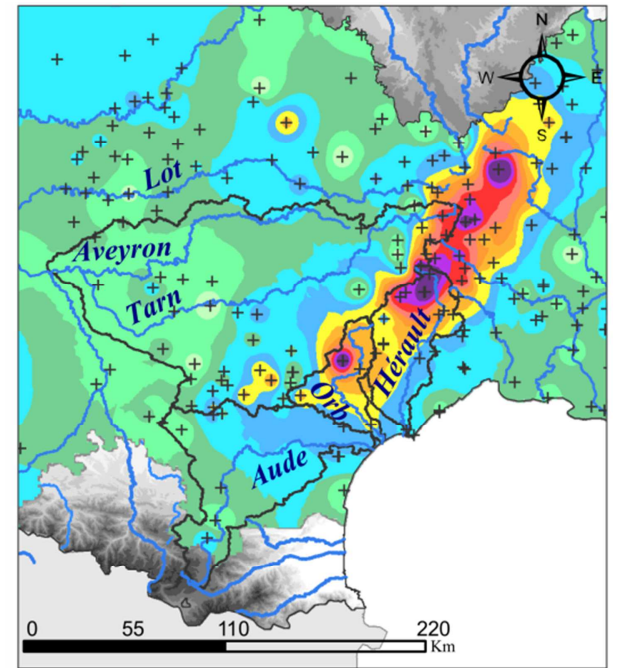

(a)

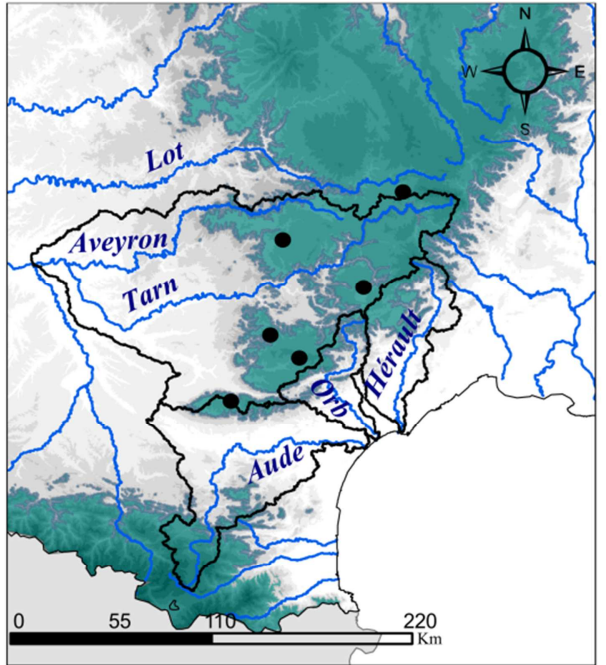

(b)

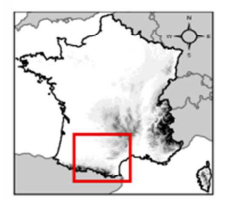

\section{Legend}

$\square$ Catchment area

Previous rainfall (1st October to 25th February)

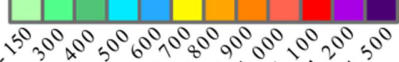
520000000000
Snow cover

+ Rain gauge

- River network

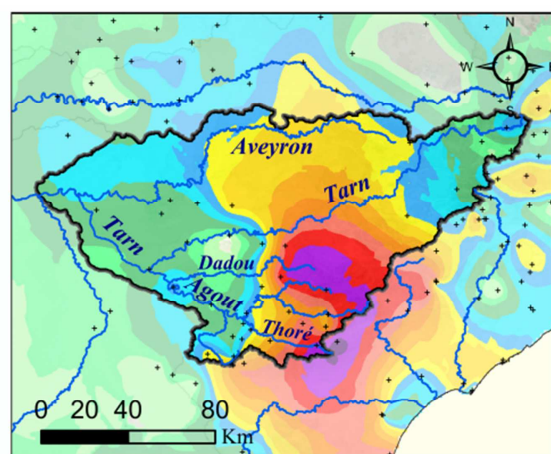

(a)

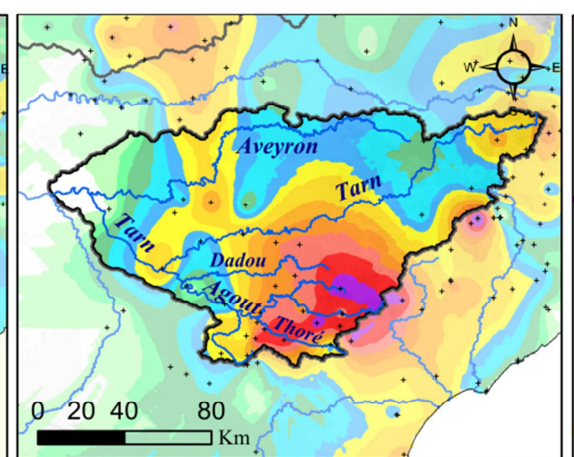

(b)

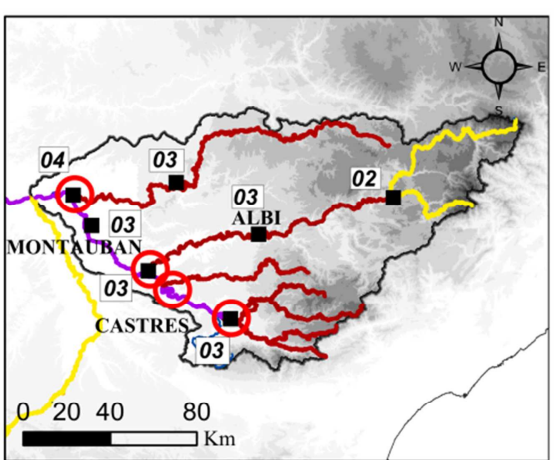

(c)

\section{Legend}

Precipitations (mm)

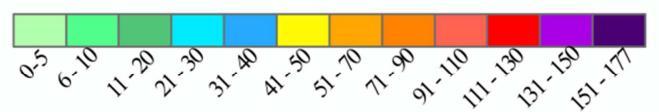

Tarn catchment area

$+\quad$ Rain gauge
- Hydrological station

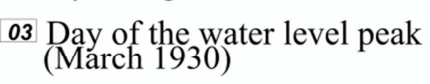

Coincidence of flood flows
Return period $\mathrm{T}$ (years) of the peak discharge

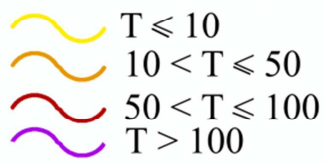

Figure 16. Tarn catchment: (a) daily precipitation on 1st of March 1930; (b) daily precipitation on 2nd of March 1930; (c) peak flow (date and return period) 


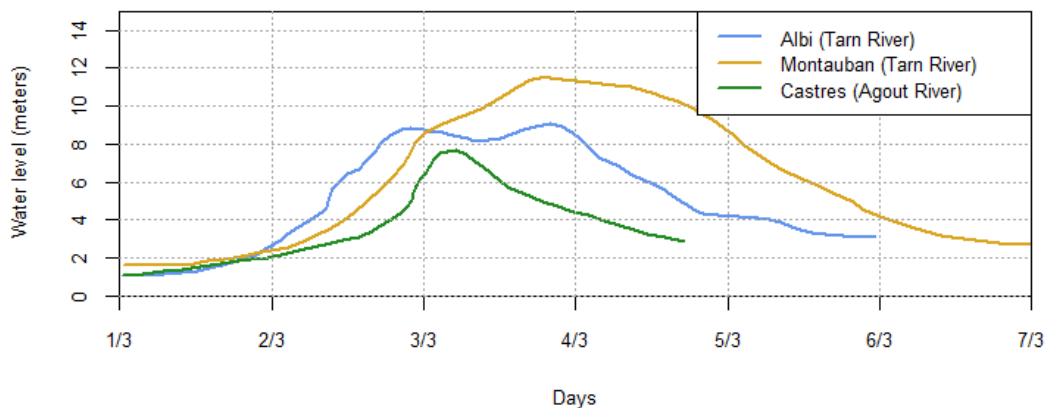

Figure 17. Water levels at three gauging stations for the Tarn and Agout Rivers during the March 1930

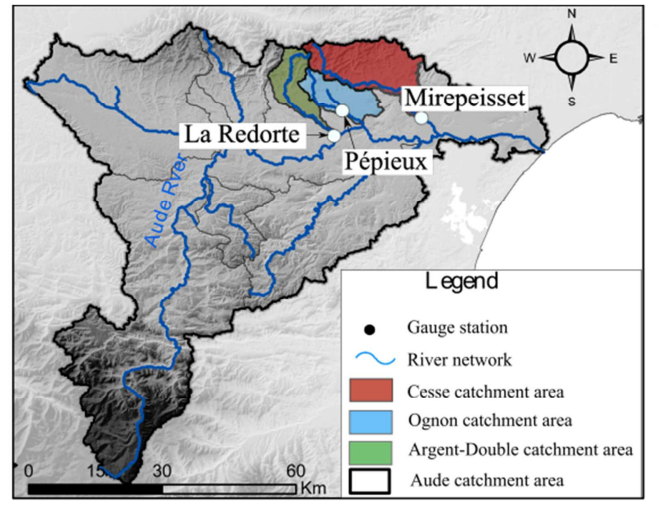

(a)

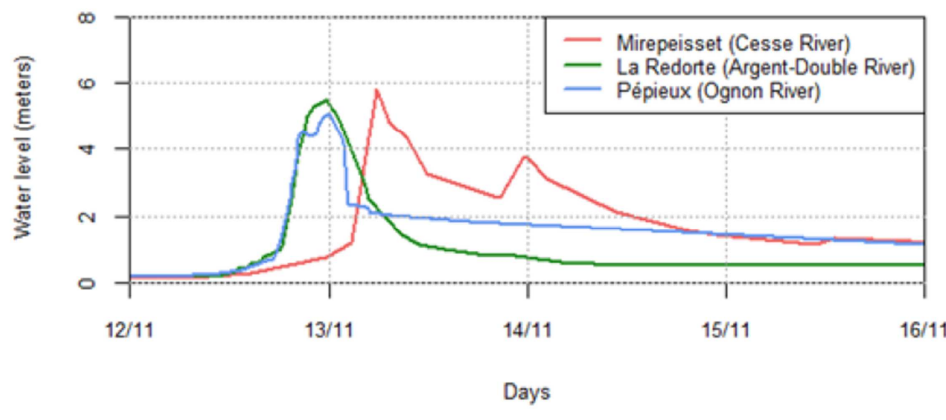

(b)

Figure 18. Aude river: (a) location of three sub-catchments; (b) water level at three gauging stations during the November 1999 flood event

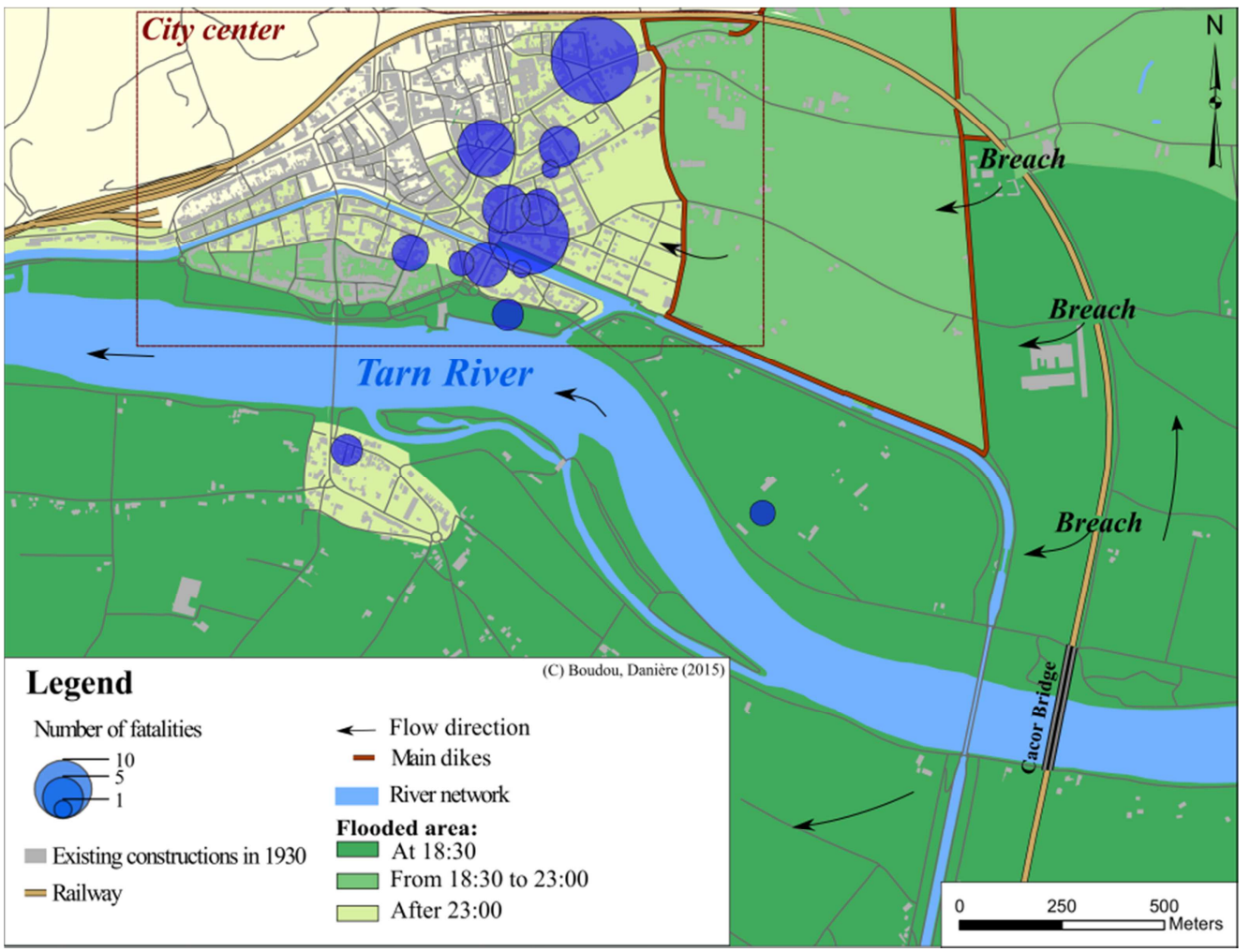

Figure 19. March 1930 flood chronology and fatalities in the city of Moissac 